\title{
Antimicrobial and Antioxidant Performance of Various Essential Oils and Natural Extracts and Their Incorporation into Biowaste Derived Poly(3-hydroxybutyrate-co-3-hydroxyvalerate) Layers Made from Electrospun Ultrathin Fibers
}

\author{
Kelly J. Figueroa-Lopez ${ }^{1}\left(\mathbb{D}\right.$, António A. Vicente ${ }^{2} \mathbb{D}$, Maria A. M. Reis ${ }^{3}$, Sergio Torres-Giner ${ }^{1}$ (D) \\ and Jose M. Lagaron ${ }^{1, *(\mathbb{D})}$ \\ 1 Novel Materials and Nanotechnology Group, Institute of Agrochemistry and Food Technology (IATA), \\ Spanish National Research Council (CSIC), Calle Catedrático Agustín Escardino Benlloch 7, Paterna, \\ 46980 Valencia, Spain; kjfigueroal@iata.csic.es (K.J.F.-L.); storresginer@iata.csic.es (S.T.-G.) \\ 2 Centre of Biological Engineering, University of Minho, Campus Gualtar, 4710-057 Braga, Portugal; \\ avicente@deb.uminho.pt \\ 3 UCIBIO-REQUIMTE, Departamento de Química, Faculdade de Ciências e Tecnologia, \\ Universidade Nova de Lisboa, Campus de Caparica, 2829-516 Caparica, Portugal; amr@fct.unl.pt \\ * Correspondence: lagaron@iata.csic.es
}

Received: 4 January 2019; Accepted: 19 January 2019; Published: 23 January 2019

\begin{abstract}
In this research, the antibacterial and antioxidant properties of oregano essential oil (OEO), rosemary extract (RE), and green tea extract (GTE) were evaluated. These active substances were encapsulated into ultrathin fibers of poly(3-hydroxybutyrate-co-3-hydroxyvalerate) (PHBV) derived from fruit waste using solution electrospinning, and the resultant electrospun mats were annealed to produce continuous films. The incorporation of the active substances resulted in PHBV films with a relatively high contact transparency, but it also induced a slightly yellow appearance and increased the films opacity. Whereas OEO significantly reduced the onset of thermal degradation of PHBV, both the RE and GTE-containing PHBV films showed a thermal stability profile that was similar to the neat PHBV film. In any case, all the active PHBV films were stable up to approximately $200^{\circ} \mathrm{C}$. The incorporation of the active substances also resulted in a significant decrease in hydrophobicity. The antimicrobial and antioxidant activity of the films were finally evaluated in both open and closed systems for up to 15 days in order to anticipate the real packaging conditions. The results showed that the electrospun OEO-containing PHBV films presented the highest antimicrobial activity against two strains of food-borne bacteria, as well as the most significant antioxidant performance, ascribed to the films high content in carvacrol and thymol. Therefore, the PHBV films developed in this study presented high antimicrobial and antioxidant properties, and they can be applied as active layers to prolong the shelf life of the foods in biopackaging applications.
\end{abstract}

Keywords: PHBV; oregano; rosemary; green tea; electrospun nanofibers; antibacterial; antioxidant

\section{Introduction}

The packaging industry requires the development of new plastic materials with active properties, based on the demand by consumers for safer and more nutritive food [1]. Moreover, the growing concern over the environmental problems caused by petroleum-derived materials has led to the search for new renewable raw materials for the development of compostable packaging [2,3]. Polyhydroxyalkanoates (PHAs) are amongst the most promising biopolymers, 
being a group of totally renewable, biodegradable, and biocompatible aliphatic polyesters. PHAs are synthesized in the cytoplasm of a wide range of bacteria from glucose-rich substrates [4,5]. Some PHAs, such as poly(3-hydroxybutyrate) (PHB), poly(3-hydroxybutyrate-co-3hydroxyvalerate) (PHBV), poly(3-hydroxybutyrate-co-4-hydroxybutyrate) (P(3HB-co-4HB)), and poly(3-hydroxybutyrate-co-3-hydroxyhexanoate) (PHBH) are currently being employed to develop bioplastic packaging articles, such as injection-molded pieces, compression-molded sheets, and films [6-9].

Active packaging technology is mostly related to materials and articles that are intended to extend food shelf life, and also to improve packaged food conditions by interacting with the food product and/or with its internal packaging environment. Active packaging materials are usually designed to deliberately incorporate components, which would then release and/or absorb substances into or from the packaged food or the environment surrounding the food [10]. Active packaging systems can therefore extend the shelf life of food products and reduce food waste by maintaining the quality of food products for longer, increasing product safety by securing the foods against pathogens, and enhancing the convenience of food processing, distribution, retailing, and consumption [11]. Concerning the active packaging materials, these are classified as either active scavenging types (e.g., oxygen scavengers) [12] or active releasing types (e.g., antioxidants) [13]. Active releasing-type packaging can provide novel "extra" functions, such as aromatic, antioxidant, and long-term antimicrobial properties [14]. In particular, active-releasing antimicrobial packaging applications are directly related to food microbial safety, as well as to shelf life extension, by preventing the growth of spoilage and/or pathogenic microorganisms $[15,16]$. The growth of spoilage microorganisms can not only reduce the food shelf life, but it can also endanger public health (particularly in the case of pathogenic microorganisms).

Active properties can be conferred by the incorporation into the packaging materials of substances with inherent antioxidant and antimicrobial properties, such as essential oils (EOs) [17], natural extracts (NEs) [18], and/or inorganic and metal nanoparticles [19]. EOs are volatile compounds obtained from aromatic plants that produced them naturally as secondary metabolites [20]. EOs and NEs are mainly composed of terpenoids, phenolic, and aromatic compounds, and their composition can widely vary depending on the edaphoclimatic characteristics of the plant, the part of the plant (i.e., flower, seed, leaves, fruits, stems, and others), and the extraction procedure [21]. There is great interest in the use of these natural products because they are classified as generally recognized as safe (GRAS) food additives by the Food and Drug Administration (FDA) [22].

In line with this, over the last few years, different EOs and NEs have been proposed as alternative sources of antimicrobials in packaging materials. Within the great variety of EOs, oregano essential oil (OEO) from Origanum vulgare is well known for its antioxidative and antimicrobial activities [23]. The EO content in the oregano plant fluctuates from $0.5-2 \%$ [24] up to $7 \%$ [25]. Its main constituents are the isomer phenols, carvacrol and thymol, which represent up to $80 \%$ and $64 \%$, respectively [26]. In addition, up to $52 \%$ of each of their precursor monoterpenes, p-cymene and $\gamma$-terpinene, as well as terpinen-4-ol, linalool, $\beta$-myrcene, trans-sabinene hydrate, and $\beta$-caryophyllene, are also present [27]. Rosemary extract (RE), which is obtained from Rosmarinus officinalis, is an aromatic plant belonging to the Lamiaceae family [28], and it also presents strong antimicrobial and antifungal properties [29]. The active properties of RE are primarily conferred by its phenolic, and the volatile constituents carnosol, carnosic acid, and rosmarinic acid [30]. Its minor components may have a potential influence on biological activity due to the possibility of synergistic effects amongst their components [31]. Finally, green tea tree extract (GTE) obtained from Camellia sinensis has gained significant attention in recent years. GTE is mainly composed of gallic acid, theobromine, chlorogenic acid, and caffeic acid [32]. In view of the potential uses of these natural products as effective antimicrobial and antioxidants for food preservation, they can be great candidates for incorporation into PHA films to generate active packaging articles. 
Since most EOs and NEs are volatile compounds, they require the use of manufacturing methods that are carried out at room temperature to preserve their original properties. In this sense, the electrospinning technique is an emerging technology in the food packaging field [33,34], which is based on the application of electrostatic forces to polymer solutions to generate polymer fibers with diameters ranging from below $100 \mathrm{~nm}$ to several micrometers. Owing to the high surface-to-volume ratio of the electrospun fibers and the controllable pore size of the electrospun mats, several active and bioactive applications have been proposed in recent years [35], including the development of novel antimicrobial systems [36]. Since the electrospinning technique is frequently performed at room temperature, it facilitates the processing of thermolabile substances [37]. In addition, in a packaging application context, the ultrathin electrospun PHA fiber mats can be further converted into continuous films through the application of a thermal post-treatment below the polymer's melting temperature $\left(T_{m}\right)$, i.e., the so-called annealing $[38,39]$.

The objective of this research was to develop, for the first time, electrospun PHBV films containing OEO, RE, and GTE, in order to obtain active packaging layers with antioxidant and antimicrobial properties. Likewise, the morphological, optical, and thermal properties of the electrospun biopolymer films were also evaluated.

\section{Materials and Methods}

\subsection{Materials}

PHBV copolyester was produced at a pilot-plant scale at the Universidade NOVA de Lisboa (Lisboa, Portugal). This biopolymer was obtained using mixed microbial cultures fed with fermented fruit waste derived from the manufacturing of fruit juice, supplied by SumolCompal S.A. (Lisbon, Portugal). The molar fraction of the 3-hydroxyvalerate (HV) in the copolyester used was $20 \%$. The synthesis, purification, and characterization details of this biopolymer was thoroughly described in Reference [39].

Chloroform, reagent grade with $99.8 \%$ purity, and methanol, HPLC grade with $99.9 \%$ purity, were purchased from Panreac S.A. (Barcelona, Spain). Additionally, 1-Butanol, reagent grade with 99.5\% purity, and 2,2-diphenyl-1-picrylhydrazyl radical (DPPH) were purchased from Sigma Aldrich S.A. (Madrid, Spain).

OEO had a purity $>99 \%$ and a relative density of $0.925-0.955 \mathrm{~g} / \mathrm{mL}$. RE presented a relative density of $0.915-0.926 \mathrm{~g} / \mathrm{mL}$, an acidity index of $\leq 1 \mathrm{mg} \mathrm{KOH} / \mathrm{g}$, an iodine index of $80.0-145.0 \%$, a saponification index of $180-200 \mathrm{mg} \mathrm{KOH} / \mathrm{g}$, and a peroxide index of $\leq 5.0 \mathrm{meqO}_{2} / \mathrm{kg}$. GTE showed a relative density of $0.915-0.925 \mathrm{~g} / \mathrm{mL}$, an acidity index of $\leq 1 \mathrm{mg} \mathrm{KOH} / \mathrm{g}$, an iodine index of $80-145 \%$, a saponification index of $188-195 \mathrm{mg} \mathrm{KOH} / \mathrm{g}$, and a peroxide index of $\leq 5.0 \mathrm{meq} \mathrm{O}_{2} / \mathrm{Kg}$. All natural products were obtained from Gran Velada S.L. (Zaragoza, Spain) and were processed as received.

\subsection{Preparation of the Solutions}

The PHBV solution was prepared by dissolving 10\% (wt./vol.) of biopolymer in a chloroform/ 1-butanol 75:25 (vol./vol.) mixture, both reagent grades, at room temperature. The OEO, RE, and GTE, were all added to the solution at $10 \mathrm{wt} . \%$ in relation to the PHBV and stirred for $24 \mathrm{~h}$ until a single-phase solution was obtained.

\subsection{Characterization of the Solution Properties}

All the PHBV solutions were analyzed in terms of their viscosity, surface tension, and conductivity. The apparent viscosity ( $\eta$ a) was determined at $100 \mathrm{~s}^{-1}$ using a rotational viscosity meter Visco BasicPlus L from Fungilab S.A. (San Feliu de Llobregat, Spain). The surface tension was measured following the Wilhemy plate method using an EasyDyne K20 tensiometer from Krüss GmbH (Hamburg, Germany). The conductivity was evaluated using a conductivity meter HI9819X from Hanna Instruments 
(Woonsocket, Rhode Island, USA). All the measurements were carried out at room temperature and in triplicate.

\subsection{Electrospinning}

The PHBV solutions containing OEO, RE, and GTE were each electrospun for $3 \mathrm{~h}$ onto an aluminum foil using a high-throughput electrospinning/electrospraying pilot line Fluidnatek ${ }^{\circledR}$ LE-500 with temperature and relative humidity (RH) control, which was manufactured and commercialized by Bioinicia S.L. (Valencia, Spain). The solutions were then processed at $25{ }^{\circ} \mathrm{C}$ and $40 \% \mathrm{RH}$ under a constant flow using a 24 emitter multi-nozzle injector, scanning vertically onto the metallic plate. A dual polarization added voltage of $38 \mathrm{kV}$, and a flow-rate of $4 \mathrm{~mL} / \mathrm{h}$ per single emitter and a tip-to-collector distance of $20 \mathrm{~cm}$ were used. A neat PHBV solution was electrospun in identical conditions as the control.

Thereafter, an annealing treatment was applied to the resultant electrospun mats. This process was performed in a 4122-model press from Carver, Inc. (Wabash, IN, USA) at $125^{\circ} \mathrm{C}$, for $5 \mathrm{~s}$, without pressure. The resultant film samples had an average thickness in the 60-80 $\mu \mathrm{m}$ range.

\subsection{Characterization of the Electrospun Materials}

\subsubsection{Film Thickness}

Before testing, the thickness of the PHBV films containing the natural products was measured using a digital micrometer (S00014, Mitutoyo, Corp., Kawasaki, Japan) with $\pm 0.001 \mathrm{~mm}$ accuracy. Measurements were performed and averaged at five different points, one in each corner and one in the middle.

\subsubsection{Morphology}

The morphology of the electrospun PHBV fibers and their films containing the OEO, RE, and GTE were examined by scanning electron microscopy (SEM). The micrographs were taken using a Hitachi S-4800 electron microscope (Tokyo, Japan), at an accelerating voltage of $10 \mathrm{kV}$ and a working distance of 8-10 mm. The samples were previously sputtered with a gold-palladium mixture for 3 min under vacuum. The average fiber diameter was determined via the ImageJ software v 1.41 using at least 20 SEM images.

\subsubsection{Transparency}

The light transmission of the PHBV films was determined in specimens of $50 \times 30 \mathrm{~mm}^{2}$ by quantifying the absorption of light at wavelengths between 200 and $700 \mathrm{~nm}$, using an ultraviolet-visible (UV-Vis) spectrophotometer VIS3000 from Dinko Instruments (Barcelona, Spain). The transparency value $(T)$ of the films was calculated using Equation (1) [1], whereas their opacity value $(O)$ was determined using Equation (2) [40]:

$$
\begin{gathered}
T=\frac{A_{600}}{L} \\
O=A_{500} L
\end{gathered}
$$

where $A_{500}$ and $A_{600}$ are the absorbance values at 500 and $600 \mathrm{~nm}$, respectively, and $L$ is the film thickness (mm). 


\subsubsection{Color}

The PHBV films color was determined using a chroma meter CR-400 (Konica Minolta, Tokyo, Japan). The color difference ( $\left.\Delta E^{*}\right)$ was calculated using the following Equation (3) [1], as defined by the Commission Internationale de l'Eclairage (CIE):

$$
\Delta E^{*}=\left[\left(\Delta L^{*}\right)^{2}+\left(\Delta a^{*}\right)^{2}+\left(\Delta b^{*}\right)^{2}\right]^{0.5}
$$

where $\Delta E^{*}, \Delta L^{*}, \Delta a^{*}$, and $\Delta b^{*}$ correspond to the differences between the color parameters of the sample films and the values of the control film $\left(a^{*}=0.87, b^{*}=-0.38, L^{*}=89.82\right)$.

\subsubsection{Thermal Analysis}

Thermogravimetric analysis (TGA) of the neat OEO, RE, and GTE in their liquid form, and the PHBV films, was performed under a nitrogen atmosphere in a Thermobalance TG-STDA Mettler Toledo model TGA/STDA851e/LF/1600 analyzer (Greifensee, Switzerland). The TGA curves were obtained after conditioning the samples in the sensor for $5 \mathrm{~min}$ at $30^{\circ} \mathrm{C}$. The samples were then heated from $25^{\circ} \mathrm{C}$ to $700{ }^{\circ} \mathrm{C}$, at a heating rate of $10^{\circ} \mathrm{C} / \mathrm{min}$. All tests were carried out in triplicate.

\subsubsection{Water Contact Angle Measurements}

The PHBV films surface wettability was evaluated using dynamic water contact angle (WCA) measurements in an optical tensiometer (Theta Lite, Staffordshire, UK). Five droplets were seeded at $5 \mu \mathrm{L} / \mathrm{s}$ on the film surfaces of each studied material sizing of $2 \times 5 \mathrm{~cm}^{2}$, in triplicate, and the resulting average contact angle was calculated.

\subsubsection{Antimicrobial Activity}

Staphylococcus aureus (S. aureus) CECT240 (ATCC 6538p) and Escherichia coli (E. coli) CECT434 (ATCC 25922) strains were obtained from the Spanish Type Culture Collection (CECT, Valencia, Spain) and stored in phosphate buffered saline (PBS), with $10 \mathrm{wt} . \%$ tryptic soy broth (TSB, Conda Laboratories, Madrid, Spain) and $10 \mathrm{wt} . \%$ glycerol (99.5\% purity, Sigma Aldrich S.A. Madrid, Spain) at $-80{ }^{\circ} \mathrm{C}$. Prior to each study, a loopful of bacteria was transferred to $10 \mathrm{~mL}$ of TSB and incubated at $37^{\circ} \mathrm{C}$ for $24 \mathrm{~h}$. A $100 \mu \mathrm{L}$ aliquot from the culture was again transferred to the TSB and grown at $37^{\circ} \mathrm{C}$ to the mid-exponential phase of growth. The approximate count of $5 \times 10^{5} \mathrm{CFU} / \mathrm{mL}$ of culture had an absorbance value of 0.20 , as determined by the optical density at $600 \mathrm{~nm}$ (UV 4000 spectrophotometer, Dinko Instruments, Barcelona, Spain).

The minimum inhibitory concentration (MIC) and minimum bactericide concentration (MBC) of the OEO, RE, and GTE against the selected food-borne bacteria was tested following the plate micro-dilution protocol, as described in the Methods for Dilution Antimicrobial. Susceptibility Tests for Bacteria That Grow Aerobically; Approved Standard Tenth. Edition (M07-A10) by the Clinical and Laboratory Standards Institute (CLSI). For this, a 96-well plate with an alpha numeric coordination system (columns 12 and rows $\mathrm{A}-\mathrm{H}$ ) was used, where $10 \mu \mathrm{L}$ of the tested samples were introduced into the wells with $90 \mu \mathrm{L}$ of the bacteria medium. In the wells corresponding to A, B, C, E, F, and G columns, different concentrations of the natural products, that is, $0.312,0.625,1.25,2.5,5,10,20,40,80$, $160 \mu \mathrm{L} / \mathrm{mL}$, were tested, in triplicate, from rows 1 to 10 . Columns D and $\mathrm{H}$ were used as control of the natural extracts in the TSB without bacteria. Row 11 was taken as a positive control, that is, only the TSB, and row 12 was used as a negative control, that is, S. aureus and E. coli in the TSB. The plates were incubated at $37^{\circ} \mathrm{C}$ for $24 \mathrm{~h}$. Thereafter, $10 \mu \mathrm{L}$ of resazurin sodium salt (MP biologicals, Illkirch, France), a metabolic indicator, was added to each well and incubated again at $37^{\circ} \mathrm{C}$ for $2 \mathrm{~h}$. Upon obtaining the resazurin change, the wells were read through the color difference. The MIC and MBC values were determined as the lowest concentration of the natural products presenting bacteriostatic and bactericide effects, respectively [41]. 
The antimicrobial performance of the electrospun PHBV films was evaluated using a modification of the Japanese Industrial Standard (JIS) Z2801 (ISO 22196:2007) [42]. To this end, a microorganism suspension of $S$. aureus and $E$. coli was applied onto the test films, that is, containing the natural extracts, and the negative control film, that is, without the natural extracts, all sizing $1.5 \times 1.5 \mathrm{~cm}^{2}$. Tests were performed in either hermetically closed or open vials with a volume of $20 \mathrm{~mL}$. After incubation at $24{ }^{\circ} \mathrm{C}$ and at a relative humidity (RH) of, at least, $95 \%$ for $24 \mathrm{~h}$, the bacteria were recovered with PBS, 10 -fold serially diluted, and incubated at $37^{\circ} \mathrm{C}$ for $24 \mathrm{~h}$ in order to quantify the number of viable bacteria by a conventional plate count. The antimicrobial activity was evaluated after 1 (initial day), 8 , and 15 days. The value of the antimicrobial reduction (R) was calculated following Equation (4):

$$
R=\left[\log \left(\frac{B}{A}\right)-\log \left(\frac{C}{A}\right)\right]=\log \left(\frac{B}{C}\right)
$$

where $A$ is the average of the number of viable bacteria on the control film sample immediately after inoculation, $B$ is the average of the number of viable bacteria on the control film sample after $24 \mathrm{~h}$, and $C$ is the average of the number of viable bacteria on the test film sample after $24 \mathrm{~h}$. Three replicate experiments were performed for each sample and the following assessment was conducted: Nonsignificant $(R<0.5)$, slight $(R \geq 0.5$ and $<1)$, significant $(R \geq 1$ and $<3)$, and strong $(R \geq 3)$ as in Reference [43].

\subsubsection{Antioxidant Activity}

The DPPH inhibition assay was used to evaluate the free radical scavenging activity of the neat OEO, RE, GTE in their oil forms, in the electrospun PHBV fibers (at day 1) and their corresponding films (at 1, 8, and 15 days). Samples were weighed in triplicate in cap vials and then an aliquot of the DPPH solution $(0.05 \mathrm{~g} / \mathrm{L}$ in methanol) was added to each one. Vials without samples were also prepared as controls. All the samples were prepared and immediately stored at room temperature for $2 \mathrm{~h}$ in darkness. After this, the absorbance of the solution was measured at $517 \mathrm{~nm}$ in the UV 4000 spectrophotometer from Dinko Instruments. Results were expressed as the percentage of inhibition to DPPH following Equation (5) [44] and $\mu$ g equivalent of trolox per gram of sample, employing a previously prepared calibration curve of trolox.

$$
\text { Inhibition DPPH (\%) }=\frac{A_{\text {Control }}-\left(A_{\text {sample }}-A_{\text {blank }}\right)}{A_{\text {control }}} * 100
$$

where $A_{\text {control }}, A_{\text {blank }}$, and $A_{\text {sample }}$ are the absorbance values of the DPPH solution, methanol with the test sample, and the test sample, respectively.

\subsubsection{Statistical Analysis}

The solution properties, color, transparency, and opacity values, and contact angle values were evaluated through analysis of variance (ANOVA) using STATGRAPHICS Centurion XVI v 16.1.03 from StatPoint Technologies, Inc. (Warrenton, VA, USA). Fisher's least significant difference (LSD) was used at the $95 \%$ confidence level $(p<0.05)$. Mean values and standard deviations were also calculated.

\section{Results}

\subsection{Solution Properties}

The use of polymer solution with the adequate properties is a key parameter to obtain uniform fibers during electrospinning [45]. In Table 1, the viscosity, surface tension, and conductivity of the PHBV solutions containing OEO, RE, and GTE at $10 \mathrm{wt} . \%$ are shown. The neat PHBV solution, without $\mathrm{OEO}$ and NEs, showed the highest viscosity value, that is, $212.4 \mathrm{cP}$. This value was relatively similar to that reported by Melendez-Rodriguez et al. [39], who obtained a value of viscosity of $296.8 \mathrm{cP}$ for a 
PHBV solution in 2,2,2-trifluoroethanol (TFE) at $2 \mathrm{wt} \%$. This difference could be mainly ascribed to the solvent type and, more likely, to the use of a biopolymer with a higher molecular weight $\left(M_{W}\right)$. When OEO, RE, and GTE were added, the viscosity of the PHBV solution slightly decreased. This effect could be ascribed to a reduction of the molecular cohesion forces in the biopolymer due to the presence of the active substances. This result was in agreement with, for instance, previous research works reported by Arfa et al. [46] and Jouki et al. [47], showing that the addition of either OEO or its active components decreased the apparent viscosity of polymer solutions of mucilage and soy protein (SP). In any case, for all the here-prepared PHBV solutions, the viscosity values were within the range of values reported by other authors, that is, from 1 to 20 poise (P), for the formation of homogeneous fibers during electrospinning [48].

Table 1. Solution properties of poly(3-hydroxybutyrate-co-3-hydroxyvalerate) (PHBV) containing oregano essential oil (OEO), rosemary extract (RE), and green tea tree extract (GTE).

\begin{tabular}{cccc}
\hline Samples & Apparent Viscosity (cP) & Surface Tension (mN/m) & Conductivity ( $\mu$ s) \\
\hline PHBV & $212.4 \pm 0.04^{\mathrm{a}}$ & $25.3 \pm 0.05^{\mathrm{a}}$ & $0.40 \pm 0.01^{\mathrm{a}}$ \\
PHBV + OEO & $205.5 \pm 0.01^{\mathrm{b}}$ & $25.5 \pm 0.07^{\mathrm{a}}$ & $0.42 \pm 0.02^{\mathrm{a}}$ \\
PHBV + RE & $208.1 \pm 0.03^{\mathrm{c}}$ & $25.4 \pm 0.09^{\mathrm{a}}$ & $0.41 \pm 0.01^{\mathrm{a}}$ \\
PHBV + GTE & $206.9 \pm 0.05^{\mathrm{d}}$ & $25.5 \pm 0.06^{\mathrm{a}}$ & $0.39 \pm 0.01^{\mathrm{a}}$ \\
\hline \multicolumn{4}{c}{${ }^{\mathrm{a}-\mathrm{d}}$ Different letters in the same column indicate a significant difference $(p<0.05)}$.
\end{tabular}

The surface tension and conductivity of the solutions showed no significant differences $(p>0.05)$. However, it is worthy to mention that other authors have observed changes in the latter parameters when homogenization treatments (e.g., ultrasound, sonication, etc.) were applied to polymer solutions containing different EOs and NEs $[49,50]$. Moreover, in the case of polymer emulsions, the incorporation of these natural extracts into the oil or water phases resulted in an increasing drop size that destabilized the emulsion [51]. Therefore, the similar values observed for the neat PHBV solution and the PHBV solutions containing the OEO, RE, and GTE suggested that a high homogenization was achieved in all cases. Therefore, it was considered that the resulting solutions presented the adequate values for being processed by electrospinning.

\subsection{Morphology}

The morphology of the electrospun ultrathin neat PHBV fibers and the PHBV fibers containing the OEO, RE, and GTE was analyzed by SEM and the images are shown in Figure 1. The neat PHBV fibers, without EOs and NEs, were relatively uniform and presented a mean diameter of approximately $1 \mu \mathrm{m}$, as seen in Figure 1A. The morphology of the here-obtained electrospun ultrathin PHBV fibers was similar to those fibers reported by Melendez-Rodriguez et al. [39], showing diameters of $\sim 1.32 \mu \mathrm{m}$. The PHBV fibers containing $10 \mathrm{wt} \%$ OEO, RE, and GTE are presented in Figure 1B-D, respectively. The diameters of the fibers were relatively similar, with a mean size of approximately $0.8 \mu \mathrm{m}$. The reduction achieved in the fiber diameter could be related to the slightly lower viscosities observed for the PHBV solutions containing the active substances. It was also evident that all the electrospun fibers were uniform and smooth, without any superficial and structural defects, which indicated that the addition of both EOs and NEs did not alter the fiber formation during electrospinning.

Figure 2 shows the SEM images of the electrospun materials, after annealing at $125{ }^{\circ} \mathrm{C}$, in their cross-section and top views. In all cases, one can observe that the thermal post-treatment on the electrospun mats resulted in the formation of a continuous film. Figure 2A corresponds to the cross-section of the neat PHBV film, that is, without OEO and NEs, which presented an average thickness of $\sim 80 \mu \mathrm{m}$. In Figure 2B, one can observe that the film sample also exhibited a homogeneous surface without cracks and/or pores. Similar morphologies were reported, for instance, by Cherpinski et al. [38] for electrospun PHB fibers thermally post-treated at $160{ }^{\circ} \mathrm{C}$. The particular change from fiber-based to film-like morphology was ascribed to a process of fibers coalescence during 
annealing. Figure 2C,E,G show the cross-sections of the electrospun PHBV films containing OEO, RE, and GTE, respectively. The thicknesses of all the film samples were kept at $\sim 80 \mu \mathrm{m}$. The presence of a certain number of pores can be related to the partial evaporation of the oily materials enclosed in the PHBV film during the thermal post-treatment. Similar voids were observed in the electrospun PHBV films derived from biowaste by Melendez-Rodriguez et al. [39], when temperatures close to $T_{m}$ were applied, which was ascribed to the partial material melting and/or degradation. However, in Figure 2D,F,H, showing the top view of the film samples containing the active substances, it can be seen that the PHBV films still showed a smooth and homogeneous surface without pores and cracks. Therefore, despite the fact that the active substances were partially released during the film-forming process, a good compatibility and then a high solubility of OEO and the NEs with the PHBV matrix was attained.

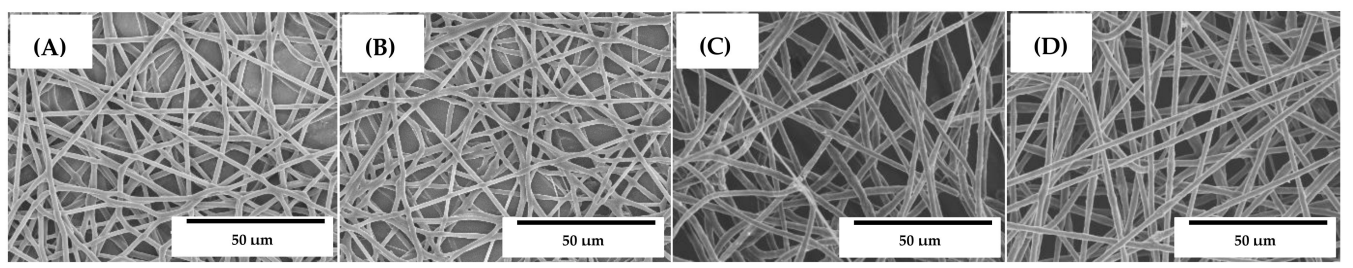

Figure 1. Scanning electron microscopy (SEM) micrographs of the electrospun fibers of: (A) Neat poly(3-hydroxybutyrate-co-3-hydroxyvalerate) (PHBV); (B) Oregano essential oil (OEO)-containing PHBV; (C) Rosemary extract (RE)-containing PHBV; (D) Green tea tree extract (GTE)-containing PHBV. Scale markers of $50 \mu \mathrm{m}$.

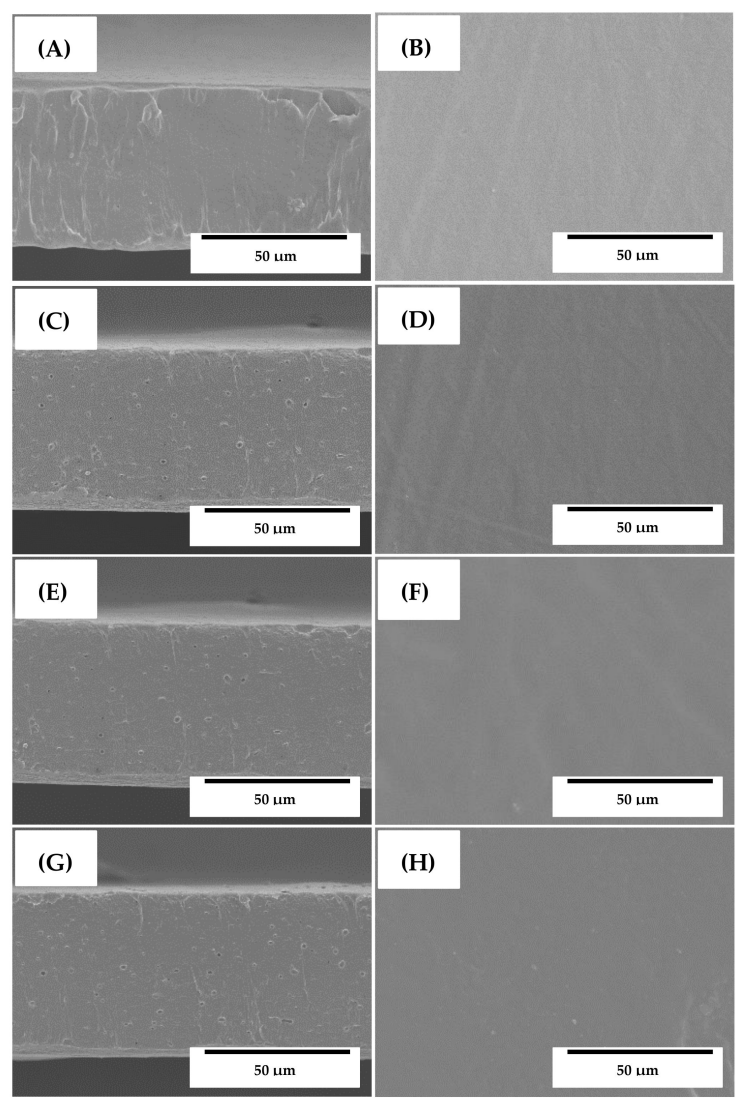

Figure 2. Scanning electron microscopy (SEM) micrographs of the electrospun films in their cross-section (left column) and top view (right column) of: (A,B) Neat poly(3-hydroxybutyrate-co-3hydroxyvalerate) (PHBV); (C,D) Oregano essential oil (OEO)-containing PHBV; (E,F) Rosemary extract (RE)-containing PHBV; (G,H) Green tea tree extract (GTE)-containing PHBV. Scale markers of $50 \mu \mathrm{m}$. 


\subsection{Optical Properties}

Figure 3 shows the visual aspect of the electrospun PHBV films to evaluate their contact transparency. The effects of the addition of OEO and the NEs on the color coordinates $\left(L^{*}, a^{*}, b^{*}\right)$ and the values of $\triangle E, T$, and $O$ of the electrospun PHBV films are shown in Table 2. One can observe that all the here-prepared PHBV films presented a high contact transparency, but they also developed a slightly yellow appearance when the active substances were incorporated. The $\Delta E$ values of the active PHBV films with respect to the neat PHBV film were 8.36, 7.52, and 15.82 for the films with OEO, $\mathrm{RE}$, and GTE, respectively. Therefore, the highest color change was observed for the GTE-containing PHBV film. The main changes observed were based on a decrease in brightness $\left(L^{*}\right)$ and an increase in the $b^{*}$ coordinate, that is, a yellower material, which was related to the intrinsic color of the added active substances.

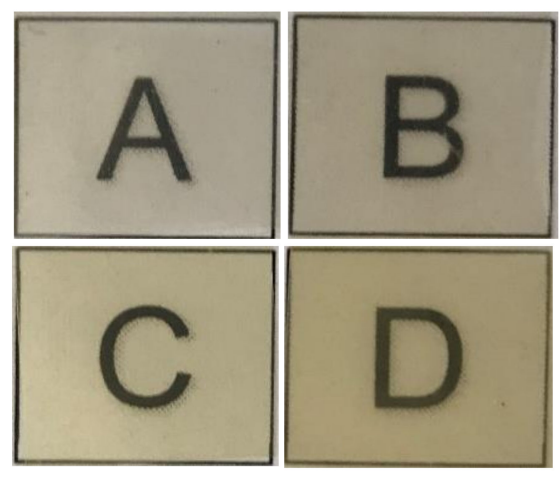

Figure 3. Visual aspect of the electrospun films of: (A) Neat poly(3-hydroxybutyrate-co-3-hydroxyvalerate) (PHBV); (B) Oregano essential oil (OEO)-containing PHBV; (C) Rosemary extract (RE)-containing PHBV; (D) Green tea tree extract (GTE)-containing PHBV. Films are $1.5 \times 1.5 \mathrm{~cm}^{2}$.

Table 2. Color parameters $\left(\Delta E^{*}, a^{*}, b^{*}\right.$, and $\left.L^{*}\right)$ and transparency characteristics of the electrospun films of poly(3-hydroxybutyrate-co-3-hydroxyvalerate) (PHBV) containing oregano essential oil (OEO), rosemary extract (RE), and green tea tree extract (GTE).

\begin{tabular}{ccccccc}
\hline Samples & $\boldsymbol{a}^{*}$ & $\boldsymbol{b}^{*}$ & $\boldsymbol{L}^{*}$ & $\boldsymbol{\Delta} \boldsymbol{E}^{*}$ & $\boldsymbol{T}$ & $\boldsymbol{O}$ \\
\hline PHBV & $0.87 \pm 0.07^{\mathrm{a}}$ & $-0.38 \pm 0.02^{\mathrm{a}}$ & $89.82 \pm 0.06^{\mathrm{a}}$ & - & $3.13 \pm 0.02^{\mathrm{a}}$ & $0.016 \pm 0.06^{\mathrm{a}}$ \\
PHBV + OEO & $1.13 \pm 0.05^{\mathrm{b}}$ & $6.67 \pm 0.03^{\mathrm{b}}$ & $85.35 \pm 0.07^{\mathrm{b}}$ & $8.36 \pm 0.08^{\mathrm{a}}$ & $3.55 \pm 0.03^{\mathrm{b}}$ & $0.019 \pm 0.08^{\mathrm{b}}$ \\
PHBV + RE & $0.04 \pm 0.01^{\mathrm{c}}$ & $6.67 \pm 0.08^{\mathrm{b}}$ & $87.33 \pm 0.01^{\mathrm{c}}$ & $7.52 \pm 0.06^{\mathrm{b}}$ & $6.44 \pm 0.02^{\mathrm{c}}$ & $0.026 \pm 0.05^{\mathrm{c}}$ \\
PHBV + GTE & $0.07 \pm 0.09^{\mathrm{c}}$ & $14.45 \pm 0.05^{\mathrm{c}}$ & $84.38 \pm 0.03^{\mathrm{d}}$ & $15.82 \pm 0.05^{\mathrm{c}}$ & $16.42 \pm 0.06^{\mathrm{d}}$ & $0.067^{ \pm} \pm 0.04^{\mathrm{d}}$ \\
\hline
\end{tabular}

$\boldsymbol{a}^{*}$ : red/green coordinates (+a red, - a green); $\boldsymbol{b}^{*}$ : yellow/blue coordinates (+b yellow, $-\mathrm{b}$ blue); $\boldsymbol{L}^{*}$ : Luminosity $(+\mathrm{L}$ luminous, $-\mathrm{L}$ dark); $\Delta E^{*}$ : color differences; $T$ : transparency; $O$ : opacity. ${ }^{\text {a-d }}$ Different letters in the same column indicate a significant difference $(p<0.05)$.

One can also observe that the OEO-containing PHBV film presented a transparency similar to that of the neat PHBV film, both having $T$ values in the range of 3-4, which indicated a greater passage of visible light through the material. However, the incorporation of RE and, particularly, of GTE resulted in an increase of $T$ up to values of 6.4 and 16.4, respectively. Therefore, the capacity of transmission of visible and UV light of the films was significantly reduced by the addition of RE and GTE $(p<0.05)$, causing a phenomenon of light scattering due to the characteristic tones of the active substances. Similarly, whereas opacity was kept relatively low for the neat PHBV film and the OEO-containing PHBV films, which both had $O$ values in the 0.015-0.02 range, these values increased up to 0.026 and 0.067 for the RE- and GTE-containing PHBV films, respectively. Then, the presence of the latter active substances, particularly GTE, reduced the transparency properties by blocking the passage of UV-Vis light and it increased the opacity of the films, caused by the scattering of light. However, as other authors have previously stated, this property can be also a desired characteristic in some packaging materials for the protection of foodstuff from light, especially UV radiation, which can cause lipid oxidation in the food products [1,40]. In this sense, the work reported by Gómez-Estaca et al. [52] also 
concluded that the addition of certain NEs to fish gelatin films decreased the transparency of the films and increased the opacity of the final material.

\subsection{Thermal Stability}

Figure 4 includes the weight loss curves of the free active substances and of the electrospun PHBV films obtained by TGA. The curves for the neat OEO, RE, and GTE are shown in Figure 4A, while the values of the onset degradation temperature, that is, the temperature at $5 \%$ weight loss $\left(T_{5 \%}\right)$, degradation temperature $\left(T_{\text {deg }}\right)$, and residual mass at $700{ }^{\circ} \mathrm{C}$ are gathered in Table 3 . One can observe that OEO presented the lowest thermal stability, showing values of $T_{5 \%}$ and $T_{\text {deg }}$ of $101.5^{\circ} \mathrm{C}$ and $178.4{ }^{\circ} \mathrm{C}$, respectively, with a respective weight loss of $74.16 \%$ at $T_{\text {deg }}$, corresponding to the volatilization and/or degradation of low- $\mathrm{M}_{\mathrm{W}}$ volatile compounds present in the OEO (e.g., carvacrol, thymol, and pinene). In this sense, other authors have also reported that the EOs and NEs of oregano are among the most thermally unstable active substances. For instance, Barbieri et al. [53] reported that $96-97 \%$ of the OEO's weight was lost between $200{ }^{\circ} \mathrm{C}$ and $216{ }^{\circ} \mathrm{C}$, attributed to its volatilization. In another work, Yang et al. [54] determined a significant degradation of all terpenes extracted oregano leaves in the $200-250^{\circ} \mathrm{C}$ range. Similarly, Gibara Guimarães et al. [55] reported the fully thermal decomposition of carvacrol, the most representative active compound of oregano, at $168{ }^{\circ} \mathrm{C}$. Opposite to OEO, both RE and GTE showed a high thermal stability with a similar mass loss profile. In particular, both active substances presented $T_{5} \%$ values over $350{ }^{\circ} \mathrm{C}$, with $T_{\text {deg }}$ values of $412.7^{\circ} \mathrm{C}(52.45 \%)$ and $411.5^{\circ} \mathrm{C}(49.89 \%)$ for RE and and GTE, respectively. Similar results, though slighlty lower, were reported for RE by Piñeros-Hernandez et al. [56], showing a significant mass loss at $300{ }^{\circ} \mathrm{C}$, corresponding to the decomposition of phenolic diterpenes, that is, carnosic acid, carnosol, and rosmarinic acid. Likewise, Cordeiro et al. [57] obtained a mass loss as low as $6 \%$ up to $190{ }^{\circ} \mathrm{C}$. In the case of GTE, López de Dicastillo et al. [58] determined that it remained stable up to the range of $200-400{ }^{\circ} \mathrm{C}$, where the thermal degradation of partially glycosylated catechins occurs. Furthermore, all active substances produced a residual mass below $1 \%$.

In Figure 4B, the weight loss curves of the electrospun PHBV films containing OEO, RE, and GTE are gathered. The neat PHBV film was thermally stable up to $251.5^{\circ} \mathrm{C}$, showing a $T_{\text {deg }}$ value of $278.7^{\circ} \mathrm{C}(47.74 \%)$ and a residual mass of $2.10 \%$. While the incorporation of RE and GTE slightly reduced the thermal stability by $5-10{ }^{\circ} \mathrm{C}$, the presence of OEO considerably reduced the onset of degradation, showing a $T_{5 \%}$ value of $197.5^{\circ} \mathrm{C}$. It is also worthy to mention, however, that all active substances increased the thermally decomposed mass at $T_{\text {deg }}$, that is, the weight values decreased to the $60-70 \%$ range. Therefore, the here-produced active PHBV films were stable up to $200{ }^{\circ} \mathrm{C}$, which certainly opened up their application as an active food packaging interlayer and/or coating.

A

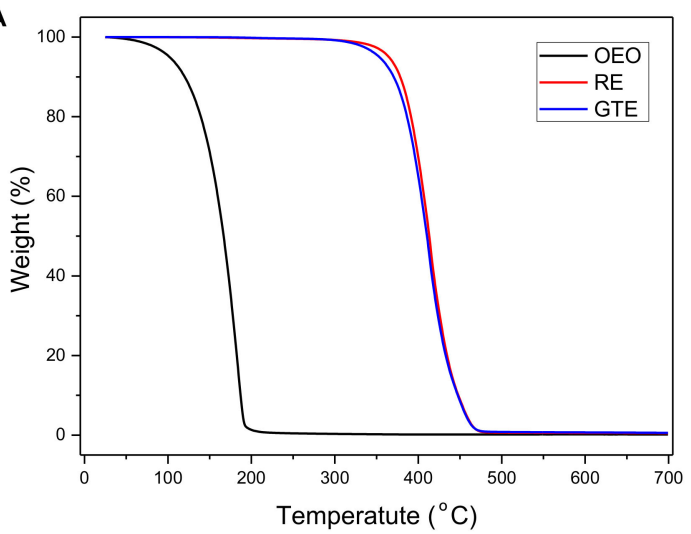

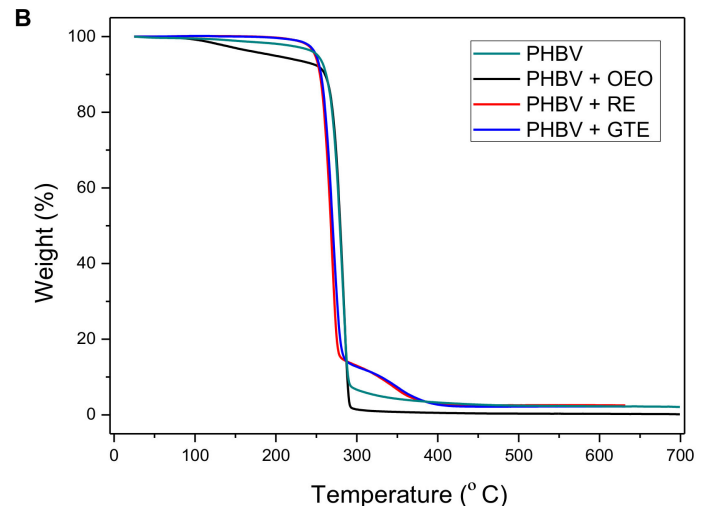

Figure 4. Weight loss as a function of temperature for: (A) Oregano essential oil (OEO), rosemary extract (RE), and green tea tree extract (GTE); (B) Electrospun films of neat poly(3-hydroxybutyrate-co-3-hydroxyvalerate) (PHBV) and PHBV containing OEO, RE, and GTE. 
Table 3. Thermal properties of oregano essential oil (OEO), rosemary extract (RE), and green tea tree extract (GTE) and of the electrospun films of poly(3-hydroxybutyrate-co-3-hydroxyvalerate) (PHBV) containing OEO, RE, and GTE in terms of temperature at $5 \%$ weight loss $\left(T_{5 \%}\right)$, degradation temperature $\left(T_{\text {deg }}\right)$, and residual mass at $700{ }^{\circ} \mathrm{C}$.

\begin{tabular}{ccccc}
\hline Sample & $\boldsymbol{T}_{\mathbf{5} \%}\left({ }^{\circ} \mathbf{C}\right)$ & $\boldsymbol{T}_{\text {deg }}\left({ }^{\circ} \mathbf{C}\right)$ & Mass Loss (\%) & Residual Mass (\%) \\
\hline OEO & 101.5 & 178.4 & 74.16 & 0.14 \\
RE & 364.0 & 412.7 & 52.45 & 0.48 \\
GTE & 352.7 & 411.5 & 49.89 & 0.56 \\
PHBV & 251.5 & 278.7 & 47.74 & 2.10 \\
PHBV + OEO & 197.5 & 283.6 & 69.58 & 0.16 \\
PHBV + RE & 248.5 & 270.8 & 60.94 & 2.49 \\
PHBV + GTE & 249.3 & 273.8 & 61.65 & 2.21 \\
\hline
\end{tabular}

\subsection{Water Contact Angle}

The water contact angle refers to the degree of affinity of water with a surface, which defines the degree of hydrophilicity/hydrophobicity of a given polymer material [59]. In Figure 5, the water drop images on the films, as well as the values of their contact angles, are shown for the electrospun PHBV films. In Figure 5A, one can observe that the neat PHBV film presented an angle of $103.61^{\circ}$, which is characteristic of hydrophobic materials [60]. In all cases, the incorporation of the active substances resulted in a significant decrease in hydrophobicity $(p<0.05)$. Figure 5B shows that the OEO-containing PHBV film presented a water contact angle of $82.23^{\circ}$, whilst these values were even lower for both the films containing RE (Figure 5C), that is, $73.86^{\circ}$, and GTE (Figure 5D), that is, $71.26^{\circ}$. The reduction achieved could be related to the presence of the oily molecules on the surfaces of the PHBV films, which decreased the surface tension. A similar decrease in the water contact angles was observed by Galus and Kadzińska [61] in whey protein isolate (WPI) edible films when almond and walnut oils were added. In any case, following the terms "hydrophobic" and "hydrophilic", defined for $\theta>65^{\circ}$ and $\leq 65^{\circ}$, respectively [62], the angles for each of the films studied were still within the hydrophobic range.

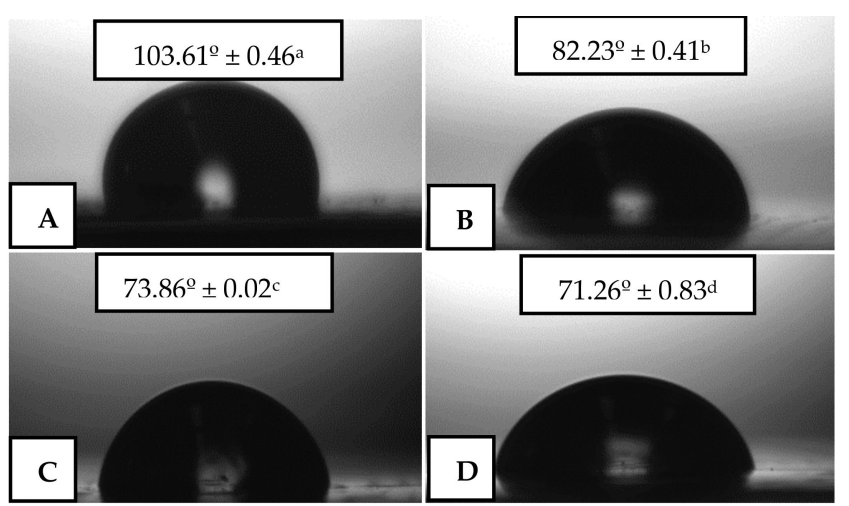

Figure 5. Water contact angle of the electrospun films of: (A) Neat poly(3-hydroxybutyrate-co-3hydroxyvalerate) (PHBV); (B) Oregano essential oil (OEO)-containing PHBV; (C) Rosemary extract (RE)-containing PHBV; (D) Green tea tree extract (GTE)-containing PHBV.

\subsection{Active Properties}

\subsubsection{Antimicrobial Activity}

The EOs and NEs obtained from aromatic plants are constituted by a wide range of active compounds that are responsible for antimicrobial and antioxidant activity, which has promoted their application in active food packaging [1,41,42]. Table 4 shows the MIC and MBC values of the neat OEO, RE, and GTE against strains of S. aureus (Gram positive, G+) and E. coli (Gram negative, G-). The results 
showed that the OEO presented the highest antibacterial effect against both bacterial strains, having achieved identical MIC and MBC values, that is, $0.625 \mu \mathrm{L} / \mathrm{mL}$, against $E$. coli, and $0.312 \mu \mathrm{L} / \mathrm{mL}$, against S. aureus. The fact that the MIC and MBC values were identical can be related to the high effectivity of the natural compounds that were achieved, at the same time, the inhibition of microbial growth and the elimination of $99.9 \%$ of the microorganisms [63]. The antimicrobial activity of the OEO has been mainly ascribed to its high content in carvacrol and thymol [64,65]. RE presented MIC values of $10 \mu \mathrm{L} / \mathrm{mL}$ and $5 \mu \mathrm{L} / \mathrm{mL}$ against E. coli and S. aureus, respectively, whereas its $\mathrm{MBC}$ values were $20 \mu \mathrm{L} / \mathrm{mL}$, against E. coli, and $10 \mu \mathrm{L} / \mathrm{mL}$, against $S$. aureus. The main compounds responsible for the antimicrobial activity of RE were $\alpha$-pinene, myrcene, camphor, 1,8-cineole, and camphene [29,66,67]. Likewise, GTE showed the lowest antimicrobial performance. This NE presented MIC values of $160 \mu \mathrm{L} / \mathrm{mL}$, against E. coli, and $80 \mu \mathrm{L} / \mathrm{mL}$, against $S$. aureus. Its $\mathrm{MBC}$ values were $160 \mu \mathrm{L} / \mathrm{mL}$, against E. coli, and $40 \mu \mathrm{L} / \mathrm{mL}$, against $S$. aureus. Gallic acid (GA), theobromine, chlorogenic acid, and caffeic acid are known to be responsible for its antimicrobial activity [32,68]. Most research related to MIC and MBC determination has been conducted with these EOs and NEs, finding that these compounds have a broad inhibition spectrum against $\mathrm{G}+$ bacteria, but they are not as efficient against some G- bacteria [69,70]. The values of the MBC and MIC for OEO were the same, while for RE and GTE, the MBC values were higher than the MIC values. This fact is related to the effectiveness of the active compounds, the susceptibility of the microorganisms, and the variation in the penetration rate of the extracts through the cell wall and the structures of the cell membrane [71,72].

Table 4. Minimum inhibitory concentration (MIC) and minimum bactericidal concentration (MBC) of oregano essential oil (OEO), rosemary extract (RE), and green tea tree extract (GTE) against S. aureus and E. coli.

\begin{tabular}{cccc}
\hline Sample & Bacteria & MIC & MBC \\
\hline \multirow{2}{*}{ OEO } & E. coli & $0.625 \mu \mathrm{L} / \mathrm{mL}$ & $0.625 \mu \mathrm{L} / \mathrm{mL}$ \\
\cline { 2 - 4 } & S. aureus & $0.312 \mu \mathrm{L} / \mathrm{mL}$ & $0.312 \mu \mathrm{L} / \mathrm{mL}$ \\
\hline \multirow{2}{*}{ RE } & E. coli & $10 \mu \mathrm{L} / \mathrm{mL}$ & $20 \mu \mathrm{L} / \mathrm{mL}$ \\
\cline { 2 - 4 } & S. aureus & $5 \mu \mathrm{L} / \mathrm{mL}$ & $10 \mu \mathrm{L} / \mathrm{mL}$ \\
\hline \multirow{2}{*}{ GTE } & E. coli & $160 \mu \mathrm{L} / \mathrm{mL}$ & $160 \mu \mathrm{L} / \mathrm{mL}$ \\
\cline { 2 - 4 } & S. aureus & $40 \mu \mathrm{L} / \mathrm{mL}$ & $80 \mu \mathrm{L} / \mathrm{mL}$ \\
\hline
\end{tabular}

The antimicrobial properties of the electrospun PHBV films containing OEO, RE, and GTE were also evaluated using the JIS Z2801 against S. aureus and E. coli bacteria, in both an open and closed system, for 1, 8, and 15 days. In relation to the open system, as shown in Table 5, one can observe that the films containing OEO showed the strongest inhibition. These films provided a strong reduction $(R \geq 3)$, that is, with a reduction of $3 \log$ units, against $S$. aureus, and also a high antimicrobial effect, though slightly lower, presenting $R$ values of 2.7-2.9 against E. coli. In the case of the films containing RE and GTE, the films yielded a bacteriostatic effect $(1 \leq \mathrm{R}<3)$ against both bacteria. The antimicrobial effect of RE was also approximately $1 \log$ units higher than that observed for GTE. These results agreed with the MIC and MBC described above, where OEO inhibited the growth of E. coli and S. aureus at lower contents, whilst RE and GTE showed higher MIC and MBC values. It is also worthy to mention that in all cases, the bacterial reduction slightly increased over the days, which can be related to the slow release of the active compounds to the surface of the films. In comparison to the previous results of electrospun antimicrobial films reported by Jeong-Ann Parka and Song-Bae Kim [73] in open systems, it was observed that the inhibition of $S$. aureus increased from a $0.6 \log$ of reduction, at the initial time, to a $1.2 \mathrm{log}$ of reduction, after $120 \mathrm{~min}$. In another study, Figueroa et al. [42] also reported an increase in the bacterial inhibition with the passage of storage days, showing a $3.9 \log$ of reduction after 10 days against $S$. aureus. 
Table 5. Antibacterial activity against $S$. aureus and E. coli of the electrospun poly(3-hydroxybutyrateco-3-hydroxyvalerate) (PHBV) films containing oregano essential oil (OEO), rosemary extract (RE), and green tea tree extract (GTE) in the open system for up to 15 days.

\begin{tabular}{|c|c|c|c|c|c|}
\hline Microorganism & & Day & $\begin{array}{c}\text { Control Sample } \\
\log (\mathrm{CFU} / \mathrm{mL})\end{array}$ & $\begin{array}{c}\text { Test Sample } \\
\log (\mathrm{CFU} / \mathrm{mL})\end{array}$ & $R$ \\
\hline \multirow{9}{*}{ S. aureus } & \multirow{3}{*}{$\mathrm{PHBV}+\mathrm{OEO}$} & 1 & $6.91 \pm 0.06$ & $3.78 \pm 0.08$ & $3.13 \pm 0.06$ \\
\hline & & 8 & $6.88 \pm 0.50$ & $3.68 \pm 0.03$ & $3.20 \pm 0.04$ \\
\hline & & 15 & $6.89 \pm 0.20$ & $3.65 \pm 0.10$ & $3.24 \pm 0.15$ \\
\hline & \multirow{3}{*}{ PHBV + RE } & 1 & $6.87 \pm 0.03$ & $4.07 \pm 0.07$ & $2.80 \pm 0.06$ \\
\hline & & 8 & $6.88 \pm 0.09$ & $4.01 \pm 0.03$ & $2.87 \pm 0.03$ \\
\hline & & 15 & $6.87 \pm 0.02$ & $3.95 \pm 0.01$ & $2.92 \pm 0.02$ \\
\hline & \multirow{3}{*}{ PHBV + GTE } & 1 & $6.91 \pm 0.10$ & $5.00 \pm 0.32$ & $1.91 \pm 0.20$ \\
\hline & & 8 & $6.89 \pm 0.23$ & $4.94 \pm 0.18$ & $1.95 \pm 0.13$ \\
\hline & & 15 & $6.92 \pm 0.11$ & $4.93 \pm 0.22$ & $1.99 \pm 0.19$ \\
\hline \multirow{9}{*}{ E. coli } & \multirow{3}{*}{$\mathrm{PHBV}+\mathrm{OEO}$} & 1 & $6.95 \pm 0.30$ & $4.24 \pm 0.09$ & $2.71 \pm 0.10$ \\
\hline & & 8 & $6.90 \pm 0.08$ & $4.09 \pm 0.10$ & $2.81 \pm 0.20$ \\
\hline & & 15 & $6.87 \pm 0.07$ & $4.01 \pm 0.03$ & $2.86 \pm 0.05$ \\
\hline & \multirow{3}{*}{ PHBV + RE } & 1 & $6.89 \pm 0.03$ & $5.00 \pm 0.06$ & $1.89 \pm 0.05$ \\
\hline & & 8 & $6.90 \pm 0.09$ & $4.96 \pm 0.07$ & $1.94 \pm 0.07$ \\
\hline & & 15 & $6.88 \pm 0.08$ & $4.91 \pm 0.09$ & $1.97 \pm 0.07$ \\
\hline & \multirow{3}{*}{ PHBV + GTE } & 1 & $6.89 \pm 0.15$ & $5.70 \pm 0.19$ & $1.19 \pm 0.17$ \\
\hline & & 8 & $6.87 \pm 0.33$ & $5.63 \pm 0.21$ & $1.24 \pm 0.23$ \\
\hline & & 15 & $6.90 \pm 0.46$ & $5.62 \pm 0.27$ & $1.28 \pm 0.31$ \\
\hline
\end{tabular}

As shown in Table 6, for all the samples, the reduction was slightly higher in the closed system than in the open one. While the films containing OEO presented the strongest inhibition $(R \geq 3)$ after 15 days of storage in the closed system against the two bacterial strains, the films that contained RE and GTE showed a significant inhibition $(1 \leq \mathrm{R}<3)$. This result could be attributed to the accumulation of volatile active compounds in the headspace of the closed chamber. There are a limited number of studies reporting the antimicrobial performance of the active films in closed systems, which indeed are more practical from the point of view of packaging and the design of containers to avoid deterioration of food products during storage. For instance, Torres-Giner et al. [74] developed a multilayer system, based on an electrospun coating of zein composite nanofibers containing thymol on a polylactide (PLA) film, that was evaluated against Listeria monocytogenes in a closed atmosphere in desiccators. It was reported that a concentration as low as $1.6 \mathrm{ppm}$ was able to produce a decrease in the CFU of about $3 \log$ units, whereas above $6.1 \mathrm{ppm}$, no CFU were detected. The high antimicrobial performance achieved was ascribed to the capacity of the electrospun material to release the bioactive in a sustained manner. The results are of potential interest in packaging applications, since the antimicrobial effect was not only successfully achieved in open packaging systems, but it also prolonged and improved over time in closed packaging systems, thereby extending the shelf life of perishable foods $[75,76]$. 
Table 6. Antibacterial activity against $S$. aureus and E. coli of the electrospun poly(3-hydroxybutyrateco-3-hydroxyvalerate) (PHBV) films containing oregano essential oil (OEO), rosemary extract (RE), and green tea tree extract (GTE) in the closed system for up to 15 days.

\begin{tabular}{|c|c|c|c|c|c|}
\hline Microorganism & & Day & $\begin{array}{c}\text { Control Sample log } \\
\text { (CFU/mL) }\end{array}$ & $\begin{array}{c}\text { Test Sample } \\
\log (\mathrm{CFU} / \mathrm{mL})\end{array}$ & $R$ \\
\hline \multirow{9}{*}{ S. aureus } & \multirow{3}{*}{$\mathrm{PHBV}+\mathrm{OEO}$} & 1 & $6.91 \pm 0.06$ & $3.78 \pm 0.08$ & $3.13 \pm 0.06$ \\
\hline & & 8 & $6.93 \pm 0.30$ & $3.52 \pm 0.90$ & $3.41 \pm 0.30$ \\
\hline & & 15 & $6.92 \pm 0.20$ & $3.33 \pm 0.08$ & $3.59 \pm 0.07$ \\
\hline & \multirow{3}{*}{ PHBV + RE } & 1 & $6.87 \pm 0.03$ & $4.07 \pm 0.07$ & $2.80 \pm 0.06$ \\
\hline & & 8 & $6.89 \pm 0.07$ & $3.92 \pm 0.05$ & $2.91 \pm 0.04$ \\
\hline & & 15 & $6.88 \pm 0.12$ & $3.86 \pm 0.15$ & $3.02 \pm 0.11$ \\
\hline & \multirow{3}{*}{ PHBV + GTE } & 1 & $6.91 \pm 0.10$ & $5.00 \pm 0.32$ & $1.91 \pm 0.20$ \\
\hline & & 8 & $6.89 \pm 0.15$ & $4.89 \pm 0.17$ & $2.00 \pm 0.11$ \\
\hline & & 15 & $6.86 \pm 0.20$ & $4.78 \pm 0.19$ & $2.08 \pm 0.21$ \\
\hline \multirow{9}{*}{ E. coli } & \multirow{3}{*}{$\mathrm{PHBV}+\mathrm{OEO}$} & 1 & $6.95 \pm 0.30$ & $4.24 \pm 0.09$ & $2.71 \pm 0.10$ \\
\hline & & 8 & $6.90 \pm 0.08$ & $3.96 \pm 0.10$ & $2.94 \pm 0.30$ \\
\hline & & 15 & $6.92 \pm 0.09$ & $3.91 \pm 0.07$ & $3.01 \pm 0.06$ \\
\hline & \multirow{3}{*}{ PHBV + RE } & 1 & $6.89 \pm 0.03$ & $5.00 \pm 0.06$ & $1.89 \pm 0.05$ \\
\hline & & 8 & $6.87 \pm 0.05$ & $4.88 \pm 0.08$ & $1.99 \pm 0.09$ \\
\hline & & 15 & $6.88 \pm 0.07$ & $4.79 \pm 0.03$ & $2.09 \pm 0.05$ \\
\hline & \multirow{3}{*}{ PHBV + GTE } & 1 & $6.89 \pm 0.15$ & $5.70 \pm 0.19$ & $1.19 \pm 0.17$ \\
\hline & & 8 & $6.91 \pm 0.11$ & $5.62 \pm 0.13$ & $1.29 \pm 0.15$ \\
\hline & & 15 & $6.90 \pm 0.28$ & $5.53 \pm 0.21$ & $1.37 \pm 0.19$ \\
\hline
\end{tabular}

\subsubsection{Antioxidant Activity}

The antioxidant activity of the EOs and NEs, obtained from aromatic plants, is conferred by their phenolic compounds. The DPPH free radical method is an antioxidant assay based on an electron-transfer that produces a violet solution in methanol. This free radical, stable at room temperature, is reduced in the presence of an antioxidant molecule (active compound), giving rise to a colorless solution [77]. The use of the DPPH assay provides an easy and rapid way to evaluate antioxidants using spectrophotometry. In the conservation of foods, substances with character antioxidants are of great interest because the main cause of food deterioration results from enzymatic reactions that trigger the oxidation of lipids and carbohydrates [78,79].

The percent inhibition and the equivalent concentration in micrograms of trolox per gram of sample of the neat OEO, RE, GTE, and of the electrospun fibers and films of the PHBV containing the active substances are shown in Table 7. One can observe that all the EOs and NEs showed DPPH radical scavenging activity. OEO presented the highest percentage of inhibition (91.96\%) attributed to its main active compounds (e.g., carvacrol, thymol, p-cymene, $\gamma$-terpinene) [64]. Similarly, Chun et al. [80] reported an inhibition percentage of $\mathrm{DPPH}$ of $82 \%$ for oregano extracts. RE presented a percentage of inhibition of $75.24 \%$, which was in agreement with, for instance, Bajalan et al. [81] who reported an inhibition percentage of DPPH of $73.69 \%$. GTE showed an inhibition of $71.77 \%$, conferred by the relative amount of catechins and GA [82]. Afroz Bakht et al. [83] studied the antioxidant activity from DPPH of five commercial teas, finding percentages of inhibition in the $24-71 \%$ range. In addition, Lu and Chen [84] reported percentages of inhibition between $33 \%$ and $62 \%$. In this sense, it is important to highlight that antioxidant activity is dependent on the quantity of secondary metabolites that the plant manages to synthesize in its development stage, which is influenced by the variety of the plant, the environmental conditions [85-87], and the extraction method used [83]. 
One can observe that the antioxidant activity decreased in the electrospun PHBV fibers containing OEO, RE, and GTE. After the electrospinning process, the fibers with OEO showed a percentage of inhibition of $43.14 \%$, whereas the fibers containing RE and GTE showed values of $25.82 \%$ and $22.12 \%$, respectively. In all cases, there was a decrease in the antioxidant activity of between $20 \%$ and 30\% compared to the pure OEO, RE, and GTE. The lower antioxidant inhibition of the active compounds inside the fibers could be related to polarity differences between the solvent and the polymer, the stirring process applied to the active solution prior to electrospinning, and the loss of volatiles compounds during the electrospinning process [44].

Table 7. Inhibition percentage (\%) of 2,2-diphenyl-1-picrylhydrazyl radical (DPPH) and concentration (eq. trolox/g sample) of DPPH for oregano essential oil (OEO), rosemary extract (RE), and green tea tree extract (GTE) and the electrospun fibers of poly(3-hydroxybutyrate-co-3-hydroxyvalerate) (PHBV) containing OEO, RE, and GTE.

\begin{tabular}{ccc}
\hline Sample & Inhibition Percentage (\%) & Concentration ( $\mu$ g eq trolox/g Sample) \\
\hline OEO & $91.96 \pm 0.03$ & $84.34 \pm 0.03$ \\
RE & $75.24 \pm 0.04$ & $62.34 \pm 0.03$ \\
GTE & $71.77 \pm 0.08$ & $61.95 \pm 0.07$ \\
PHBV + OEO & $43.14 \pm 0.07$ & $28.56 \pm 0.05$ \\
PHBV + RE & $25.82 \pm 0.07$ & $18.31 \pm 0.05$ \\
PHBV + GTE & $22.12 \pm 0.06$ & $13.14 \pm 0.04$ \\
\hline
\end{tabular}

Table 8 shows the percentages of inhibition and the equivalent concentration in micrograms of trolox per gram of sample of the electrospun PHBV films containing OEO, RE, and GTE, evaluated in the so-called open and closed systems on days 1, 8, and 15. Films containing OEO exhibited the highest inhibition of DPPH at day 1 (24.54\%), followed by films with the RE (15.59\%) and films with the GTE (11.14\%). Over time, all the films decreased their antioxidant activity, obtaining no significant differences in the results between each storage system. Thus, after 15 days, an inhibition percentage in the range of $8.83-10.55 \%$ was obtained for the films containing OEO. At this time, the inhibition percentage ranges for the films containing RE and GTE were 6.91-7.31\% and 5.45-6.68\%, respectively. As can be observed, the antioxidant activity decreased when the EOs and NEs were included in the PHBV fibers and, more intensively, when the films were formed. Likewise, during the days of storage, a continuous release of the characteristic volatile compounds of each EOs and NEs was produced, which was evidenced by the low percentage of DPPH inhibition at day 15 for all the samples. Previous reports have indicated that the degree of antioxidant power of biodegradable films is generally proportional to the amount of added antioxidant additives, while the thermal process for obtaining the films also affects the bioactivity, since most of the bioactive compounds are sensitive to temperatures above $80{ }^{\circ} \mathrm{C}[47,88]$. Regardless of this, all the films presented antioxidant performance and they can, therefore, be applied in antioxidant active packaging systems to extend the shelf life of packaged food products, thus minimizing the development of off-flavors, color and flavor changes, and nutritional losses $[89,90]$. 
Table 8. Inhibition percentage (\%) of 2,2-diphenyl-1-picrylhydrazyl radical (DPPH) and concentration (eq. trolox/g sample) of DPPH for the electrospun poly(3-hydroxybutyrate-co-3-hydroxyvalerate) (PHBV) films containing oregano essential oil (OEO), rosemary extract (RE), and green tea tree extract (GTE).

\begin{tabular}{cccccc}
\hline \multirow{2}{*}{ Sample } & Day & \multicolumn{2}{c}{ Open System } & \multicolumn{2}{c}{ Closed System } \\
\cline { 2 - 5 } & & $\begin{array}{c}\text { Inhibition } \\
\text { Percentage (\%) }\end{array}$ & $\begin{array}{c}\text { Concentration }(\mu \mathrm{g} \\
\text { eq trolox/g Sample) }\end{array}$ & $\begin{array}{c}\text { Inhibition } \\
\text { Percentage (\%) }\end{array}$ & $\begin{array}{c}\text { Concentration ( } \mu \text { g } \\
\text { eq trolox/g Sample) }\end{array}$ \\
\hline & 1 & $24.54 \pm 0.04$ & $26.48 \pm 0.04$ & $24.54 \pm 0.04$ & $26.48 \pm 0.04$ \\
PHBV + OEO & 8 & $16.08 \pm 0.08$ & $16.82 \pm 0.09$ & $17.43 \pm 0.04$ & $17.57 \pm 0.04$ \\
& 15 & $14.90 \pm 0.06$ & $15.75 \pm 0.06$ & $15.24 \pm 0.01$ & $16.47 \pm 0.01$ \\
PHBV + RE & 1 & $15.59 \pm 0.02$ & $16.31 \pm 0.02$ & $15.59 \pm 0.02$ & $16.31 \pm 0.02$ \\
& 8 & $10.42 \pm 0.08$ & $10.27 \pm 0.08$ & $13.50 \pm 0.01$ & $13.97 \pm 0.01$ \\
PHBV + GTE & 15 & $7.310 \pm 0.04$ & $7.710 \pm 0.04$ & $8.200 \pm 0.15$ & $8.120 \pm 0.02$ \\
& 1 & $11.14 \pm 0.04$ & $11.79 \pm 0.04$ & $11.14 \pm 0.04$ & $11.79 \pm 0.04$ \\
& 15 & $8.910 \pm 0.10$ & $8.760 \pm 0.10$ & $9.960 \pm 0.02$ & $9.820 \pm 0.02$ \\
& & $6.680 \pm 0.11$ & $6.540 \pm 0.11$ & $7.800 \pm 0.02$ & $8.250 \pm 0.02$ \\
\hline
\end{tabular}

\section{Conclusions}

The evaluation of the active properties, that is, antimicrobial and antioxidant properties, of OEO, RE, and GTE showed that OEO was the active substance that presented the highest antimicrobial activity against $S$. aureus and $E$. coli. This effect was mainly attributed to the effectiveness of its most representative active compounds, that is, carvacrol and thymol, showing identical MIC and MBC values of 0.312 and $0.625 \mu \mathrm{L} / \mathrm{mL}$, respectively. The antioxidant activity of $\mathrm{OEO}$ was also higher than that for the RE and GTE. In particular, the percentage of inhibition of the DPPH was 91.96\%. Thereafter, these active substances were incorporated at $10 \mathrm{wt} . \%$ into fruit waste derived PHBV by electrospinning. To this end, the solution properties of the PHBV containing OEO, RE, and GTE were first evaluated to determine the optimal conditions to obtain homogenous fibers. The diameters of the fibers were relatively similar, with a mean size of approximately $\sim 0.8 \mu \mathrm{m}$, being uniform and smooth, without any superficial and structural defects. It was observed that the addition of the OEO and the NEs did not alter the fiber formation during electrospinning or the morphology of the electrospun ultrathin PHBV fibers. A good compatibility and, then, high solubility of the OEO and NEs with the PHBV matrix was considered.

In order to obtain an interesting active continuous layer to be applied in the design of biopackaging, the electrospun mats of the PHBV fibers containing the active substances were subjected to a thermal post-treatment at $125^{\circ} \mathrm{C}$. Continuous PHBV films of $\sim 80 \mu \mathrm{m}$, with a smooth surface were obtained, though the presence of the active substances induced a slight porosity in their cross-section. The optical properties of the PHBV films were slightly impaired by the addition of the active substances, particularly GTE, reducing their transparency from 3.13 up to 16.42 through blocking the passage of UV-Vis light and increasing their opacity, which was caused by the scattering of light. In any case, all the PHBV films were contact transparent. All active substances also decreased the values of the $T_{\text {onset }}$ by $54{ }^{\circ} \mathrm{C}$ for $\mathrm{OEO}, 3{ }^{\circ} \mathrm{C}$ for RE, and $2.2^{\circ} \mathrm{C}$ for GTE, and the thermally decomposed mass at $T_{d e g}$ decreased to the $60-70 \%$ range. However, all the active PHBV films were stable up to $200{ }^{\circ} \mathrm{C}$. Referring to the hydrophobicity of the films, the addition of active substances decreased the superficial tension of the PHBV films with respect to the control, but the angles for each of the films studied were still within the hydrophobic range. The PHBV films containing OEO, RE, and GTE showed antimicrobial activity against strains of $S$. aureus and $E$. coli in both the here-studied open and closed systems, where the bacterial reduction improved over time due to the release and accumulation of the active compounds on the film surface. The antimicrobial activity was higher in the case of the closed system due to the presence of volatiles stored in the headspace. The films containing OEO presented the highest reduction values against the two bacterial strains $(R \geq 3)$, while the films containing $R E$ and GTE showed lower reduction values $(1 \leq R<3)$, which agreed with the MIC and MBC values of the pure active substances. The antioxidant activity of the fibers and films was much lower than that of the 
neat active substances, which was related to entrapment and loss during electrospinning and film processing, and which was also reduced with the passage of days due to the continuous release of the active compounds.

The here-developed electrospun PHBV layers with OEO, RE, and GTE are potential candidates for use in the design of sustainable active multilayer biopackaging. The antimicrobial and antioxidant performance of these materials is advantageous to prolonging the shelf life of foods, delaying the proliferation of microorganisms, and the enzymatic oxidation of foodstuffs.

Author Contributions: K.J.F.-L. performed all the experiments, measurements, data analysis, and wrote the manuscript draft. S.T.-G. proposed, planned, guided the execution of the research work, and wrote and edited the manuscript. A.A.V. provided the active substances and co-wrote the manuscript. M.A.M. Reis synthesized and characterized the biopolymer. J.M.L. supervised the research and performed the project administration.

Funding: This research was supported by the Ministry of Science, Innovation, and Universities (MICIU) program number AGL2015-63855-C2-1-R and by the EU H2020 project YPACK (reference number 773872).

Acknowledgments: K.J.F.-L. is a recipient of a Santiago Grisolía (GRISOLIAP/2017/101) grant of the Generalitat Valenciana (GVA) and S.T.-G. is on a Juan de la Cierva - Incorporación contract (IJCI-2016-29675) from MICIU.

Conflicts of Interest: The authors declare no conflict of interest.

\section{References}

1. Figueroa-Lopez, K.J.; Andrade-Mahecha, M.M.; Torres-Varga, O.L. Development of antimicrobial biocomposite films to preserve the quality of bread. Molecules 2018, 23, 212. [CrossRef] [PubMed]

2. Atarés, L.; Chiralt, A. Essential oils as additives in biodegradable films and coatings for active food packaging. Trends Food Sci. Technol. 2016, 48, 51-62. [CrossRef]

3. Requena, R.; Vargas, M.; Chiralt, A. Obtaining antimicrobial bilayer starch and polyester-blend films with carvacrol. Food Hydrocoll. 2018, 83, 118-133. [CrossRef]

4. Lenz, R.W.; Marchessault, R.H. Bacterial polyesters: Biosynthesis, biodegradable plastics and biotechnology. Biomacromolecules 2005, 6, 1-8. [CrossRef] [PubMed]

5. Sudesh, K.; Abe, H.; Do, Y. Synthesis, structure and properties of polyhydroxyalkanoates: Biological polyesters. Prog. Polym. Sci. 2000, 25, 1503-1555. [CrossRef]

6. Torres-Giner, S.; Montanes, N.; Boronat, T.; Quiles-Carrillo, L.; Balart, R. Melt grafting of sepiolite nanoclay onto poly(3-hydroxybutyrate-co-4-hydroxybutyrate) by reactive extrusion with multi-functional epoxy-based styrene-acrylic oligomer. Eur. Polym. J. 2016, 84, 693-707. [CrossRef]

7. Torres-Giner, S.; Montanes, N.; Fombuena, V.; Boronat, T.; Sanchez-Nacher, L. Preparation and characterization of compression-molded green composite sheets made of poly(3-hydroxybutyrate) reinforced with long pita fibers. Adv. Polym. Technol. 2018, 37, 1305-1315. [CrossRef]

8. Arifin, W.; Kuboki, T. Effects of thermoplastic elastomers on mechanical and thermal properties of glass fiber reinforced poly(3-hydroxybutyrate-co-3-hydroxyhexanoate) composites. Polym. Compos. 2018, 39, E1331-E1345. [CrossRef]

9. Torres-Giner, S.; Hilliou, L.; Melendez-Rodriguez, B.; Figueroa-Lopez, K.J.; Madalena, D.; Cabedo, L.; Covas, J.A.; Vicente, A.A.; Lagaron, J.M. Melt processability, characterization, and antibacterial activity of compression-molded green composite sheets made of poly(3-hydroxybutyrate-co-3-hydroxyvalerate) reinforced with coconut fibers impregnated with oregano essential oil. Food Packag. Shelf Life 2018, 17, 39-49. [CrossRef]

10. López-Rubio, A.; Almenar, E.; Hernandez-Muñoz, P.; Lagarón, J.M.; Catalá, R.; Gavara, R. Overview of active polymer-based packaging technologies for food applications. Food Rev. Int. 2004, 20, 357-387. [CrossRef]

11. Torres-Giner, S.; Gil, L.; Pascual-Ramírez, L.; Garde-Belza, J.A. Packaging: Food waste reduction. In Encyclopedia of Polymer Applications, 3 Volume Set; Mishra, M., Ed.; CRC Press, Taylor and Francis Group: Boca Raton, FL, USA, 2018; pp. 1990-2009.

12. Cherpinski, A.; Gozutok, M.; Sasmazel, H.T.; Torres-Giner, S.; Lagaron, J.M. Electrospun oxygen scavenging films of poly(3-hydroxybutyrate) containing palladium nanoparticles for active packaging applications. Nanomaterials 2018, 8, 469. [CrossRef] [PubMed] 
13. Domínguez, R.; Barba, F.J.; Gómez, B.; Putnik, P.; Bursać Kovačevićc, D.; Pateiro, M.; Santos, E.M.; Lorenzo, J.M. Active packaging films with natural antioxidants to be used in meat industry: A review. Food Res. Int. 2018, 113, 93-101. [CrossRef] [PubMed]

14. Ge, L.; Zhu, M.; Li, X.; Xu, Y.; Ma, X.; Shi, R.; Li, D.; Mu, C. Development of active rosmarinic acid-gelatin biodegradable films with antioxidant and long-term antibacterial activities. Food Hydrocoll. 2018, 83, 308-316. [CrossRef]

15. Irkin, R.; Esmer, O.K. Novel food packaging systems with natural antimicrobial agents. J. Food Sci. Technol. 2015, 52, 6095-6111. [CrossRef] [PubMed]

16. Appendini, P.; Hotchkiss, J.H. Review of antimicrobial food packaging. Innov. Food Sci. Emerg. Technol. 2002, 3, 113-126. [CrossRef]

17. Ribeiro-Santos, R.; Andrade, M.; Sanches-Silva, A. Application of encapsulated essential oils as antimicrobial agents in food packaging. Curr. Opin. Food Sci. 2017, 14, 78-84. [CrossRef]

18. Nguimjeu, C.; Moundanga, S.; Sadaka, F.; Dony, P.; Plasseraud, L.; Boni, G.; Brachais, L.; Vroman, I.; Brachais, C.H.; Tighzert, L.; et al. Suitability and effectiveness of active packaging for food contact: A study of sorption/desorption and antimicrobial performances of some natural extracts in packaging. In 18th IAPRI World Packaging Conference; DEStech Publications, Inc.: Lancaster, PA, USA, 2012; pp. 15-22.

19. Hoseinnejad, M.; Jafari, S.M.; Katouzian, I. Inorganic and metal nanoparticles and their antimicrobial activity in food packaging applications. Crit. Rev. Microbiol. 2018, 44, 161-181. [CrossRef]

20. Teixeira, B.; Marques, A.; Ramos, C.; Neng, N.R.; Nogueira, J.M.F.; Saraiva, J.A.; Nunes, M.L. Chemical composition and antibacterial and antioxidant properties of commercial essential oils. Ind. Crop. Prod. 2013, 43, 587-595. [CrossRef]

21. Raut, J.S.; Karuppayil, S.M. A status review on the medicinal properties of essential oils. Ind. Crop. Prod. 2014, 62, 250-264. [CrossRef]

22. FDA. Code of Federal Regulations-Title 21-Food Drugs. Chapter I-Food Drug Adm. Dep. Heal. Hum. Serv. Subchapter b-Food Hum. Consum. (Continued), Part 182-Subst. Gen. Recognized as Safe (Gras); FDA: Silver Spring, MD, USA, 2016.

23. Leyva-López, N.; Gutiérrez-Grijalva, E.; Vazquez-Olivo, G.; Heredia, J. Essential oils of oregano: Biological activity beyond their antimicrobial properties. Molecules 2017, 22, 989. [CrossRef]

24. Kokkini, S.; Karousou, R.; Dardioti, A.; Krigas, N.; Lanaras, T. Autumn essential oils of greek oregano. Phytochemistry 1997, 44, 883-886. [CrossRef]

25. Gounaris, Y.; Skoula, M.; Fournaraki, C.; Drakakaki, G.; Makris, A. Comparison of essential oils and genetic relationship of origanum $\mathrm{x}$ intercedens to its parental taxa in the island of crete. Biochem. Syst. Ecol. 2002, 30, 249-258. [CrossRef]

26. Shang, X.; Wang, Y.; Zhou, X.; Guo, X.; Donga, S.; Wang, D.; Zhang, J.; Pan, H.; Zhang, Y.; Miao, X. Acaricidal activity of oregano oil and its major component, carvacrol, thymol and p-cymene against psoroptes cuniculi in vitro and in vivo. Vet. Parasitol. 2016, 226, 93-96. [CrossRef] [PubMed]

27. Burt, S.A.; Vlielander, R.; Haagsman, H.P.; Veldhuizen, E.J.A. Increase in activity of essential oil components carvacrol and thymol against Escherichia coli o157:H7 by addition of food stabilizers. J. Food Prot. 2005, 68, 919-926. [CrossRef] [PubMed]

28. Begum, A.; Sandhya, S.; Ali, S.S.; Vinod, K.R.; Reddy, S.; Banji, D. An in-depth review on the medicinal flora rosmarinus officinalis (lamiaceae). Acta Sci. Pol. Technol. Aliment. 2013, 12, 61-73.

29. Jiang, Y.; Wu, N.; Fu, Y.-J.; Wang, W.; Luo, M.; Zhao, C.-J.; Zu, Y.-G.; Liu, X.-L. Chemical composition and antimicrobial activity of the essential oil of rosemary. Environ. Toxicol. Pharmacol. 2011, 32, 63-68. [CrossRef]

30. Arranz, E.; Mes, J.; Wichers, H.J.; Jaime, L.; Mendiola, J.A.; Reglero, G.; Santoyo, S. Anti-inflammatory activity of the basolateral fraction of caco-2 cells exposed to a rosemary supercritical extract. J. Funct. Foods 2015, 13, 384-390. [CrossRef]

31. Hussain, A.I.; Anwar, F.; Chatha, S.A.S.; Jabbar, A.; Mahboob, S.; Nigam, P.S. Rosmarinus officinalis essential oil: Antiproliferative, antioxidant and antibacterial activities. Braz. J. Microbiol. 2010, 41, 1070-1078. [CrossRef] 
32. Fournier-Larente, J.; Morin, M.-P.; Grenier, D. Green tea catechins potentiate the effect of antibiotics and modulate adherence and gene expression in porphyromonas gingivalis. Arch. Oral Biol. 2016, 65, 35-43. [CrossRef]

33. Torres-Giner, S. Electrospun nanofibers for food packaging applications. In Multifunctional and Nanoreinforced Polymers for Food Packaging; Lagaron, J.M., Ed.; Woodhead Publishing Ltd.: Cambridge, UK, 2011; pp. 108-125.

34. Torres-Giner, S.; Busolo, M.; Cherpinski, A.; Lagaron, J.M. Electrospinning in the packaging industry. In Electrospinning: From Basic Research to Commercialization; Kny, E., Ghosal, K., Thomas, S., Eds.; The Royal Society of Chemistry: Cambridge, UK, 2018; pp. 238-260.

35. Torres-Giner, S.; Lagaron, J.M. Zein-based ultrathin fibers containing ceramic nanofillers obtained by electrospinning. I. Morphology and thermal properties. J. Appl. Polym. Sci. 2010, 118, 778-789. [CrossRef]

36. Torres-Giner, S. Novel antimicrobials obtained by electrospinning methods. In Antimicrobial Polymers; Lagaron, J.M., Ocio, M.J., López-Rubio, A., Eds.; John Wiley \& Sons, Inc.: Hoboken, NJ, USA; pp. 261-285.

37. Altan, A.; Aytac, Z.; Uyar, T. Carvacrol loaded electrospun fibrous films from zein and poly(lactic acid) for active food packaging. Food Hydrocoll. 2018, 81, 48-59. [CrossRef]

38. Cherpinski, A.; Torres-Giner, S.; Cabedo, L.; Lagaron, J.M. Post-processing optimization of electrospun submicron poly(3-hydroxybutyrate) fibers to obtain continuous films of interest in food packaging applications. Food Addit. Contam. Part A 2017, 34, 1817-1830. [CrossRef] [PubMed]

39. Melendez-Rodriguez, B.; Castro-Mayorga, J.L.; Reis, M.A.M.; Sammon, C.; Cabedo, L.; Torres-Giner, S.; Lagaron, J.M. Preparation and characterization of electrospun food biopackaging films of poly(3-hydroxybutyrate-co-3-hydroxyvalerate) derived from fruit pulp biowaste. Front. Sustain. Food Syst. 2018, 2, 1-16. [CrossRef]

40. Kanatt, S.R.; Rao, M.S.; Chawla, S.P.; Sharma, A. Active chitosan-polyvinyl alcohol films with natural extracts. Food Hydrocoll. 2012, 29, 290-297. [CrossRef]

41. Figueroa-Lopez, K.J.; Andrade-Mahecha, M.M.; Torres-Vargas, O.L. Spice oleoresins containing antimicrobial agents improve the potential use of bio-composite films based on gelatin. Food Packag. Shelf Life 2018, 17, 50-56. [CrossRef]

42. Figueroa-Lopez, K.J.; Castro-Mayorga, J.L.; Andrade-Mahecha, M.M.; Cabedo, L.; Lagaron, J.M. Antibacterial and barrier properties of gelatin coated by electrospun polycaprolactone ultrathin fibers containing black pepper oleoresin of interest in active food biopackaging applications. Nanomaterials 2018, 8, 199. [CrossRef] [PubMed]

43. Torres-Giner, S.; Torres, A.; Ferrándiz, M.; Fombuena, V.; Balart, R. Antimicrobial activity of metal cation-exchanged zeolites and their evaluation on injection-molded pieces of bio-based high-density polyethylene. J. Food Saf. 2017, 37, 1-12. [CrossRef]

44. Busolo, M.A.; Lagaron, J.M. Antioxidant polyethylene films based on a resveratrol containing clay of interest in food packaging applications. Food Packag. Shelf Life 2015, 6, 30-41. [CrossRef]

45. Rošic, R.; Pelipenko, J.; Kocbek, P.; Baumgartner, S.; Bešter-Rogač, M.; Kristl, J. The role of rheology of polymer solutions in predicting nanofiber formation by electrospinning. Eur. Polym. J. 2012, 48, 1374-1384. [CrossRef]

46. Arfa, A.B.; Chrakabandhu, Y.; Preziosi-Belloy, L.; Chalie, P.; Gontard, N. Coating papers with soy protein isolates as inclusion matrix of carvacrol. Food Res. Int. 2007, 40, 22-32. [CrossRef]

47. Jouki, M.; Yazdi, F.T.; Mortazavi, S.A.; Koocheki, A. Quince seed mucilage films incorporated with oregano essential oil: Physical, thermal, barrier, antioxidant and antibacterial properties. Food Hydrocoll. 2014, 36, 9-19. [CrossRef]

48. Bhardwaj, N.; Kundu, S.C. Electrospinning: A fascinating fiber fabrication technique. Biotechnol. Adv. 2010, 28, 325-347. [CrossRef] [PubMed]

49. Kaltsa, O.; Yanniotis, S.; Mandala, I. Stability properties of different fenugreek galactomannans in emulsions prepared by high-shear and ultrasonic method. Food Hydrocoll. 2016, 52, 487-496. [CrossRef]

50. Mahdi Jafari, S.; He, Y.; Bhandari, B. Production of sub-micron emulsions by ultrasound and microfluidization techniques. J. Food Eng. 2007, 82, 478-488. [CrossRef] 
51. Paximada, P.; Echegoyen, Y.; Koutinas, A.A.; Mandala, I.G.; Lagaron, J.M. Encapsulation of hydrophilic and lipophilized catechin into nanoparticles through emulsion electrospraying. Food Hydrocoll. 2017, 64, 123-132. [CrossRef]

52. Gómez-Estaca, J.; Montero, P.; Fernández-Martín, F.; Alemán, A.; Gómez-Guillén, M.C. Physical and chemical properties of tuna-skin and bovine-hide gelatin films with added aqueous oregano and rosemary extracts. Food Hydrocoll. 2009, 23, 1334-1341. [CrossRef]

53. Barbieri, N.; Sanchez-Contreras, A.; Canto, A.; Cauich-Rodriguez, J.V.; Vargas-Coronado, R.; Calvo-Irabien, L.M. Effect of cyclodextrins and mexican oregano (lippia graveolens kunth) chemotypes on the microencapsulation of essential oil. Ind. Crop. Prod. 2018, 121, 114-123. [CrossRef]

54. Yang, Y.; Kayan, B.; Bozer, N.; Pate, B.; Baker, C.; Gizir, A.M. Terpene degradation and extraction from basil and oregano leaves using subcritical water. J. Chromatogr. A 2007, 1152, 262-267. [CrossRef]

55. Gibara Guimarães, A.; Almeida Oliveira, M.; dos Santos Alves, R.; dos Passos Menezes, P.; Russo Serafini, M.; Antunes de Souza Araújo, A.; Pereira Bezerra, D.; Quintans Júnior, L.J. Encapsulation of carvacrol, a monoterpene present in the essential oil of oregano, with $\beta$-cyclodextrin, improves the pharmacological response on cancer pain experimental protocols. Chem. Biol. Interact. 2015, 227, 69-76. [CrossRef]

56. Pineros-Hernandez, D.; Medina-Jaramillo, C.; López-Córdoba, A.; Goyanes, S. Edible cassava starch films carrying rosemary antioxidant extracts for potential use as active food packaging. Food Hydrocoll. 2017, 63, 488-495. [CrossRef]

57. Cordeiro, A.M.T.M.; Medeiros, M.L.; Santos, N.A.; Soledade, L.E.B.; Pontes, L.F.B.L.; Souz, A.L.; Queiroz, N.; Souza, A.G. Rosemary (Rosmarinus officinalis L.) extract. J. Therm. Anal. Calorim. 2013, 113, 889-895. [CrossRef]

58. López de Dicastillo, C.; Castro-López, M.d.M.; López-Vilariño, J.M.; González-Rodríguez, M.V. Immobilization of green tea extract on polypropylene films to control the antioxidant activity in food packaging. Food Res. Int. 2013, 53, 522-528. [CrossRef]

59. Cherpinski, A.; Torres-Giner, S.; Vartiainen, J.; Peresin, M.S.; Lahtinen, P.; Lagaron, J.M. Improving the water resistance of nanocellulose-based films with polyhydroxyalkanoates processed by the electrospinning coating technique. Cellulose 2018, 25, 1291-1307. [CrossRef]

60. Zou, P.; Liu, H.; Li, Y.; Huang, J.; Yao, D. Surface dextran modified electrospun poly (3-hydroxybutyrate-co-3-hydroxyvalerate) (phbv) fibrous scaffold promotes the proliferation of bone marrow-derived mesenchymal stem cells. Mater. Lett. 2016, 179, 109-113. [CrossRef]

61. Galus, S.; Kadzińska, J. Whey protein edible films modified with almond and walnut oils. Food Hydrocoll. 2016, 52, 78-86. [CrossRef]

62. Medina-Jaramillo, C.; Ochoa-Yepes, O.; Bernal, C.; Famá, L. Active and smart biodegradable packaging based on starch and natural extracts. Carbohydr. Polym. 2017, 176, 187-194. [CrossRef] [PubMed]

63. Bravo Cadena, M.; Preston, G.M.; Van der Hoorn, R.A.L.; Townley, H.E.; Thompson, I.P. Species-specific antimicrobial activity of essential oils and enhancement by encapsulation in mesoporous silica nanoparticles. Ind. Crop. Prod. 2018, 122, 582-590. [CrossRef]

64. Castilho, P.C.; Savluchinske-Feio, S.; Weinhold, T.S.; Gouveia, S.C. Evaluation of the antimicrobial and antioxidant activities of essential oils, extracts and their main components from oregano from madeira island, portugal. Food Control 2012, 23, 552-558. [CrossRef]

65. Stefanakis, M.K.; Touloupakis, E.; Anastasopoulos, E.; Ghanotakis, D.; Katerinopoulos, H.E.; Makridis, P. Antibacterial activity of essential oils from plants of the genus origanum. Food Control 2013, 34, 539-546. [CrossRef]

66. Mohsenabadi, N.; Rajaei, A.; Tabatabaei, M.; Mohsenifar, A. Physical and antimicrobial properties of starch-carboxy methyl cellulose film containing rosemary essential oils encapsulated in chitosan nanogel. Int. J. Biol. Macromol. 2018, 112, 148-155. [CrossRef]

67. Okoh, O.O.; Sadimenko, A.P.; Afolayan, A.J. Comparative evaluation of the antibacterial activities of the essential oils of rosmarinus officinalis 1 . Obtained by hydrodistillation and solvent free microwave extraction methods. Food Chem. 2010, 120, 308-312. [CrossRef]

68. Saeed, M.; Naveed, M.; Arif, M.; Kakar, M.U.; Manzoor, R.; El-Hack, M.E.A.; Alagawany, M.; Tiwari, R.; Khandia, R.; Munjal, A.; et al. Green tea (camellia sinensis) and 1-theanine: Medicinal values and beneficial applications in humans-A comprehensive review. Biomed. Pharmacother. 2017, 95, 1260-1275. [CrossRef] [PubMed] 
69. Clarke, D.; Molinaro, S.; Tyuftin, A.; Bolton, D.; Fanning, S.; Kerry, J.P. Incorporation of commercially-derived antimicrobials into gelatin based films and assessment of their antimicrobial activity and impact. Food Control 2016, 64, 202-211. [CrossRef]

70. Rakmai, J.; Cheirsilp, B.; Mejuto, J.C.; Torrado-Agrasar, A.; Simal-Gandara, J. Physico-chemical characterization and evaluation of bio-efficacies of black pepper essential oil encapsulated in hydroxypropyl-beta-cyclodextrin. Food Hydrocoll. 2017, 65, 157-164. [CrossRef]

71. Cox, S.D.; Mann, C.M.; Markham, J.L.; Bell, H.C.; Gustafson, J.E.; Warmington, J.R.; Wyllie, S.G. The mode of antimicrobial action of the essential oil of melaleuca alternifolia (tea tree oil). J. Appl. Microbiol. 2000, 88, 170-175. [CrossRef]

72. Yong, A.-L.; Ooh, K.-F.; Ong, H.-C.; Chai, T.-T.; Wong, F.-C. Investigation of antibacterial mechanism and identification of bacterial protein targets mediated by antibacterial medicinal plant extracts. Food Chem. 2015, 186, 32-36. [CrossRef] [PubMed]

73. Park, J.-A.; Kim, S.-B. Preparation and characterization of antimicrobial electrospun poly(vinyl alcohol) nanofibers containing benzyl triethylammonium chloride. React. Funct. Polym. 2015, 93, 30-37. [CrossRef]

74. Torres-Giner, S.; Martinez-Abad, A.; Lagaron, J.M. Zein-based ultrathin fibers containing ceramic nanofillers obtained by electrospinning. Ii. Mechanical properties, gas barrier, and sustained release capacity of biocide thymol in multilayer polylactide films. J. Appl. Polym. Sci. 2014, 131, 9270-9276. [CrossRef]

75. Cruz-Gálvez, A.M.; Castro-Rosas, J.; Rodríguez-Marín, M.L.; Cadena-Ramírez, A.; Tellez-Jurado, A.; Tovar-Jiménez, X.; Chavez-Urbiola, E.A.; Abreu-Corona, A.; Gómez-Aldapa, C.A. Antimicrobial activity and physicochemical characterization of a potato starch-based film containing acetonic and methanolic extracts of hibiscus sabdariffa for use in sausage. LWT 2018, 93, 300-305. [CrossRef]

76. Khaneghah, A.M.; Bagher Hashemi, S.M.; Limbo, S. Antimicrobial agents and packaging systems in antimicrobial active food packaging: An overview of approaches and interactions. Food Bioprod. Process. 2018, 111, 1-19. [CrossRef]

77. Sentkowska, A.; Pyrzynska, K. Investigation of antioxidant interaction between green tea polyphenols and acetaminophen using isobolographic analysis. J. Pharm. Biomed. Anal. 2018, 159, 393-397. [CrossRef] [PubMed]

78. Lorenzo, J.M.; Sichetti Munekata, P.E. Phenolic compounds of green tea: Health benefits and technological application in food. Asian Pac. J. Trop. Biomed. 2016, 6, 709-719. [CrossRef]

79. Shahidi, F.; Zhong, Y. Novel antioxidants in food quality preservation and health promotion. Eur. J. Lipid Sci. Technol. 2010, 112, 930-940. [CrossRef]

80. Chun, S.-S.; Vattem, D.A.; Lin, Y.-T.; Shetty, K. Phenolic antioxidants from clonal oregano (origanum vulgare) with antimicrobial activity against helicobacter pylori. Process Biochem. 2005, 40, 809-816. [CrossRef]

81. Bajalan, I.; Rouzbahani, R.; Pirbalouti, A.G.; Maggi, F. Antioxidant and antibacterial activities of the essential oils obtained from seven iranian populations of rosmarinus officinalis. Ind. Crop. Prod. 2017, 107, 305-311. [CrossRef]

82. Hongjun Shao, S.Y.; Qi Wang, Z.Z.; Xingbin Yang, L.Z. Non-extractable polyphenols of green tea and their antioxidant, anti- $\alpha$-glucosidase capacity, and release during in vitro digestion. J. Funct. Foods 2018, 42, 129-136.

83. Afroz Bakht, M.; Geesi, M.H.; Riadi, Y.; Imran, M.; Imtiyaz Ali, M.; Jawed Ahsan, M.; Ajmal, N. Ultrasound-assisted extraction of some branded tea: Optimization based on polyphenol content, antioxidant potential and thermodynamic study. Saudi J. Biol. Sci. 2018, in press. [CrossRef]

84. Lu, M.-J.; Chen, C. Enzymatic modification by tannase increases the antioxidant activity of green tea. Food Res. Int. 2008, 41, 130-137. [CrossRef]

85. Asensio, C.M.; Grosso, N.R.; Juliani, H.R. Quality characters, chemical composition and biological activities of oregano (Origanum spp.) essential oils from central and southern argentina. Ind. Crop. Prod. 2015, 63, 203-213. [CrossRef]

86. Mechergui, K.; Jaouadi, W.; Coelho, J.P.; Larbi Khouja, M. Effect of harvest year on production, chemical composition and antioxidant activities of essential oil of oregano (Origanum vulgare subsp glandulosum (desf.) ietswaart) growing in north africa. Ind. Crop. Prod. 2016, 90, 32-37. [CrossRef]

87. Yan, F.; Azizi, A.; Janke, S.; Schwarz, M.; Zeller, S.; Honermeier, B. Antioxidant capacity variation in the oregano (Origanum vulgare L.) collection of the german national genebank. Ind. Crop. Prod. 2016, 92, 19-25. [CrossRef] 
88. Shojaee-Aliabadi, S.; Hosseini, H.; Mohammadifar, M.A.; Mohammadi, A.; Ghasemlou, M.; Ojagh, S.M.; Hosseini, S.M.; Khaksar, R. Characterization of antioxidant-antimicrobial k-carrageenan films containing satureja hortensis essential oil. Int. J. Biol. Macromol. 2013, 52, 116-124. [CrossRef] [PubMed]

89. Gómez-Estaca, J.; López-de-Dicastillo, C.; Hernández-Muñoz, P.; Catalá, R.; Gavara, R. Advances in antioxidant active food packaging. Trends Food Sci. Technol. 2014, 35, 42-51. [CrossRef]

90. Robertson, G.L. Food Packaging: Principles and Practice; CRC Press, Taylor and Francis Group: Boca Raton, FL, USA, 1998; Volume 6. 